\title{
血清および藏器 Phosphataseの研究並びに
}

\section{Phosphatase 産生について}

\author{
第 2 編 \\ 四塩化炭素, 胆管結禁, 網内系填塞の血清並びに葴器 \\ Phosphatase に及ぼす影響
}

岡山大学医学部第 2 外科教室 (主任: 覦・津田誠次名誉教授)

助手小西等

[昭和34年 2 月 5 日受䄸]

\section{粕雼}

古く Neuberg u. Karczag') (1911年)により知ら †た Phosphatase (以下 Pht. と略す) は厷く生体 内に分布して化骨, 含水炭素の酸化, 生体内触媒とし こ作用する色々な燐酸塩の生成，腸管からの吸収，腎 よりの燐酸塩排泄，前立腺の分泌等の極のて重要な生 理的，病態生理的意義を有するが，黄宣のさいに血 清の Pht.2) が增加するのを認めたのは Roberts (1930年) が最初であり，骨疾患のみならずカタル性 燕晅のさいにも血清 Pht. は增加すると述べている. つて Bodansky and Jaffe ${ }^{3)}$ (1933年) も力 タル性萲㾞及び亜急性肝资において血清 $\mathrm{Pht}$. の增加 するフを認めている.しかして黄疸時における血清 Pht. の增加といらことに対して特に重要視されるに 至つたのは, 1933年に Roberts*' が闭塞性燕疸のさ いには非閉塞性黄疸に比して著しく高いアルカリPht. (以下 Al. Pht. と略す) を示す事より、両種黄㾝の 監別䚹断に利用する事が出ると述べて以来である. 爾 来向清 Pht. と肝並ひに胆道疾患の関係について多数 の臨休的並ひに実騟的研究がなされた，King a. A

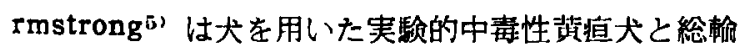
胆管結絷犬の血清 Pht. を比較して, 後者において著 しい增加を認め, 兴㾝の種類鑑別に利用し得ると述へ て Roberts の説に成している.このように肝並び に胆道疾患が血清 Pht. との間に密接な関係を有する ことが明かとなるにつれて, 肝疾患, 肝障䅞, 胆道疾 患, 胆道閉塞等の臨床的, 実駺的研究が行われて, 旰 と Pht. の間の相互関係, 臨休的意義及びその起源並 ひに血中上䄯機転等に䦎して究明か行われて来たがま だー定の定説がない.

黄㡺時における血清 Pht. の增加がどのような機転
によつて起るものであるか, 或は黄恒時において增加 をみた血清 Pht. は何処において生産せられたもので あるかについては色っの説がある.すなわち黄㡺時に おける血清 Pht. 增加の機転については, 肝の排泄機 能障碍を説く者に King a. Armstrong, ('), Flood a. Gutman7) あり, 胆计成分としての Pht. が血行中に 移行すると説く者に Freeman, Chen and Ivy8' 及 び Roberts²) がある. また血清 Pht. の起源につい ては骨性起源説 (Armstrong, (5) Flood a. Gutmann 7) 及び肝性起源説 (Freeman, Chen a. Ivy8). Winkelman a. Schiffmann') )があり,また Bodansky の如く骨性起源のほかに肝性起源のPht. の存在 を認めるものもある.こして起源在肝外に求めるもの においては，肝险の果す役割を血清 Pht.の調節にお くという考え方が有力である。

閉塞性黄疸にせよ, 非閉塞性黄疸にせよそれらの黄 疸時において堌加をみる血清 Pht. が, 黄疾の強さと 平行するか否汃につても一迹の定説がなく，諸家に よりいらいろである.それは黃瘨の発生に今日なお二 大説が存在している如く10111１2．，血清中に增强し たPht.についてもこれと全く闹一の課題が考えられ る事にもよるか, Armstrong, King a. Harris18 （1934年）及び Armstrong a. King(")(1935年) は血 清 Pht. の增加は略ヶ黄㾝の強さと平行すると述べて いるのに反し, Bodansky and Jaffe's' (1934年), Winkelman a. Schiffmann' (1939年), 及び Cantarow a. Nolson14（1937年) はこれを否定し ている.また Freeman, Chen a. Ivy» (1938年) は血清 Pht. の增加は洪㡺の有無に関せずと述べにい る. しこらしに現在 Pht. の吸収説に対しには肝の組 機学的観察による批判15) があり, 停帯説の弱点とし 
ては血中における Pht. と Bilirubin の間の不一致 が指摘されている1日).

要するに胆管閉塞或は肝障碍時に增強する Pht. に 対する肝缄の占める役割については，な捛幾多の問題 となる点があつて種々論議されて来ている．私は第 1 編において肝臟が Pht. 産生に重大な意義有するの ではないかと考えたのであるが，これら諸問題の解明 の為に四塩化炭菜注射家鬼. 胆管結架家臣及び墨汁に よる網内系充塨家雨の血清及び諸䑏器について，Al. Pht. のみならす Acid Pht. (以下 Ac. Pht. と略 す)をも生化学的に測定した.

\section{実験方法並びに実験成績}

実臨動物並びに定量法：実駼動物には $2 \mathrm{~kg}$ 前後 の成熟家鬼を用いた.これらの家鬼は一定期間一定の 食慨をもつて飼養し後実跧に供した．採血には早朝 空腹時に心穿刺により採血し，一定時間放置後遠心沈 澱して血清を分離した。

臟器片採取には第 1 編に述べた如く家鬼项動脈を切 断脱血死せしめて, 肝, 副堅, 脾, 腎皮質, 空腸上 部, 骨㵦をとり出し, 各 $0.5 \mathrm{~g}$ を秤量し, 醭素液の作 製には政山氏の白井氏变法 ${ }^{17}$ ：従い処理し，24時間 办室中に放圈し醇素を充分抽出し，ついで遠心分離し その上清を酵素液として, Shinowara-Jones-Reinh-

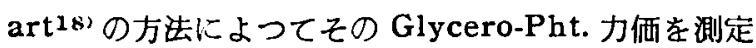
し，比色は光電比色計を使用した．副腎重量の各個差 は後で $0.5 \mathrm{~g}$ に換算してその誤差を一定にした．骨剈道 の採取は大腿骨骨䯣を用いた。単位は第 1 編と同栐 Shinowara-Jones- Reinhart 単位 (以下 S. J. R. U./dl またはS.U.と略す）で現わした. $37^{\circ} \mathrm{C}$ 瞬卵 器中における醉素作用時間㹥 1 時間とした。

\section{I 四盐化炭素投与実験}

実駼動物並びに実験方法：家鬼に四塩化炭素 毎 $\mathrm{kg}$ 当り $0.1 \mathrm{cc}$ を背部皮下に注射してその血清, 肝，

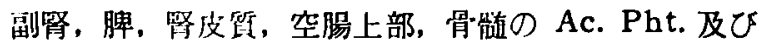
Al. Pht. を生化学的に測定した. 血清及じ脿器 Pht. 怯注射後 2 日，3 日，4 日，5 日，7 日，11日日に材 量を採取して測定を行つた。なおそのさい血清ビリル ビン量をJendrassik-cleghorn 氏定量法变法 ${ }^{10}$ 'に より併せ測定した.

実 确 成

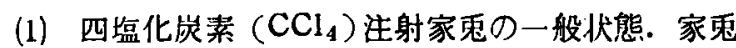
の $\mathrm{CCl}_{4}$ 注射後の一般状態を観察するに, 注射後やや 不安状態を呈するが元気で食俧も普通であるが，翌日
は元気やや不良で食愁もやや不振であるが，それも次 第に回復した。

（2） $\mathrm{CCl}_{4}$ 注射家鬼血清 Pht. 値, 血清 Ac. Pht. は $\mathrm{CCl}_{4}$ 注射後 2 日目その上年するのがみられ，2 日目 を最高として 3 日以後よりは減少がみられるが，1㘬 に注射後11日になな注射前 Pht. 值より高値を示した のがみられた（第1 表及び第 1 四)。

第 1 表 $\quad \mathrm{CCl}_{4}$ 注射家鬼 血清 Ac. Pht. 值 (S. J. R. 単位)

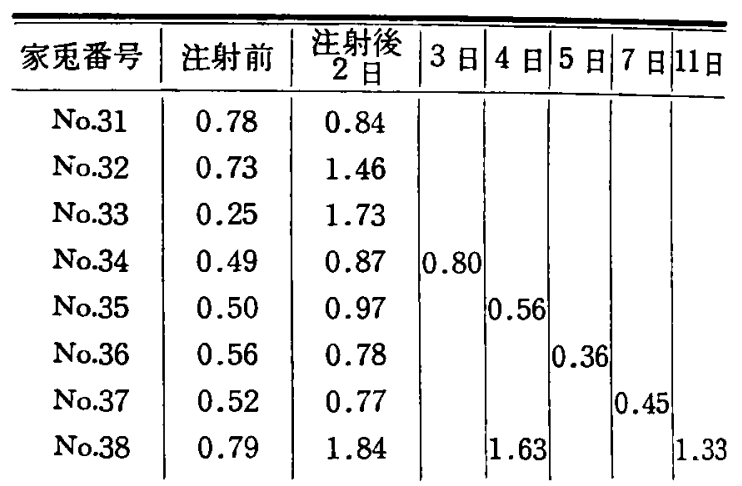

第 1 図 $\quad \mathrm{ccl}_{4}$ 注射家鬼血情AC.pht.

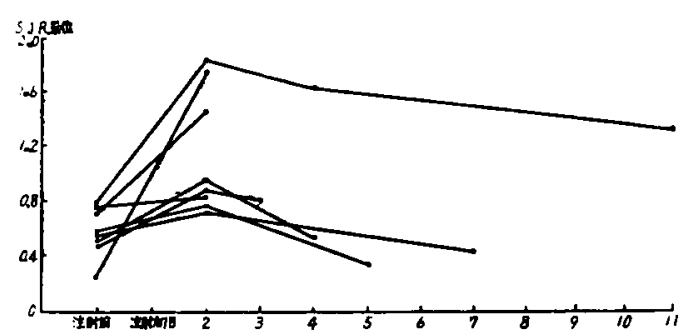

血清 Al. Pht. においても注射後2 日目急部な增加加 みられるが，これも 2 日目を最高として以後减少する のがみられ，注射後 4 日目のものはすでに注射前の Pht. 值より减少し，それ以後も更に減少の佰向が仪 られ，11日日に至るもな招减少の傾向を示した（第2 表、第 2 闵). 注射前の値より更に低値を示したこと 第 2 表 $\mathrm{CCl}^{4}$ 注射家鬼 血清 Al. Pht. 值 (S. J. R. 単位)

\begin{tabular}{|c|c|c|c|c|c|c|}
\hline 家䆜 & 注射前 & $\begin{array}{c}\text { 注射後 } \\
2 \text { 日 }\end{array}$ & 3" & 4 日 & 5 日 & $7 " \mathrm{~g}^{\prime \prime}$ \\
\hline No.31 & 6.90 & 7.62 & & & & \\
\hline No.32 & 3.45 & 10.44 & & & & \\
\hline No.33 & 2.58 & 6.74 & & & & \\
\hline No.34 & 7.62 & 16.55 & 15.33 & & & \\
\hline No.35 & 5.23 & 6.73 & & 2.7 & & \\
\hline No.36 & 4.52 & 8.36 & & & & \\
\hline No.37 & $5.38^{\circ}$ & 11.08 & & & & $p .14$ \\
\hline No.38 & 5.11 & 6.71 & & 2.93 & & \\
\hline
\end{tabular}


第 2 図 $\mathrm{ccl}_{4}$ 注射家鬼白清 Al.pht.

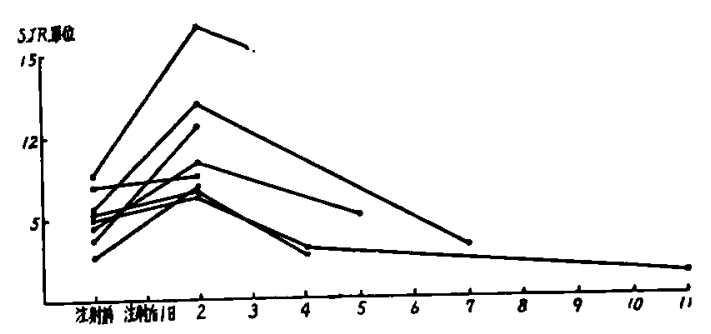

は興味ある問題である。

(3) $\mathrm{CCl}_{4}$ 注射家鬼血清ビリルビン值. 第 3 表に示 す如く血清ビリルビン値は $\mathrm{CCl}_{4}$ 注射後 2 日目には 增加がみられ以後漸减するのがみられた。しかし血清 Pht. 值との間には明らかな関係を見出すことは出来 なかつたか，Pht. 值が最高を示した注射後 2 日目に ビリルビン值もやはり最高を示した。

(4) $\mathrm{CCl}_{4}$ 注射家鬼蔵器 Pht. 值. 正常家鬼の缄器 Pht. 値はすでに第 1 編に扔いで述ベたが, 肝, 副腎, 脾, 腎, 空腸上部, 骨䯣の䑏器 Pht. 值は第 4 表に示
第3 表 $\quad \mathrm{CCl}_{4}$ 注射家鬼血清ビリルビン値

$(\mathrm{mg} / \mathrm{dl})$

\begin{tabular}{|c|c|c|c|c|c|c|c|}
\hline 家鬼番号 & 注射前 & $\begin{array}{c}\text { 注射後 } \\
2 \text { 日 }\end{array}$ & $\mid 3$ 日 & |4 日 & |5 日 & $\mid 7$ 日 & 11 日 \\
\hline No.31 & - & 0.30 & & & \multirow{8}{*}{0.22} & & \\
\hline No. 32 & - & 0.68 & & & & & \\
\hline No.33 & - & 0.72 & & & & & \\
\hline No.34 & - & 0.92 & 0.71 & & & & \\
\hline No.35 & - & 0.33 & & - & & & \\
\hline No.36 & - & 0.75 & & & & & \\
\hline No. .37 & - & 0.81 & & & & - & \\
\hline No.38 & - & 0.64 & & 0.31 & & & - \\
\hline
\end{tabular}

す通りである. $\mathrm{CCl}_{4}$ 注射家鬼の蔵器 Pht. につい 乙, 注射後 2 日目, 3 日目, 5 日目, 7 日目, 11 日目 の家鬼の肝, 副腎, 脾, 腎皮質, 空腸上部, 大腿骨々

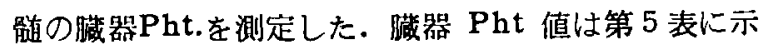
す通りである，注射後日数によるPht 值の变化はあ まりみられなかつたのですへてての平均値を求め心。

(1) 肝蔵器 Pht. 值 (第5 表), 肝 Ac. Pnt. は平

第 4 表正常家 鬼缄器 Pht. 值 (S. J. R. 単位)

\begin{tabular}{|c|c|c|c|c|c|c|c|c|c|c|c|c|c|}
\hline \multirow{2}{*}{\multicolumn{2}{|c|}{ 家秋番号 }} & \multicolumn{2}{|c|}{ 肝 } & \multicolumn{2}{|c|}{ 副 腎 } & \multicolumn{2}{|c|}{ 脾 } & \multicolumn{2}{|c|}{ 腎 } & \multicolumn{2}{|c|}{ 空腸上部 } & \multicolumn{2}{|c|}{ 骨 骮通 } \\
\hline & & Ac & $\mathrm{Al}$ & Ac & Al & Ac & Al & Ac & $\mathrm{Al}$ & Ac & $\mathrm{Al}$ & Ac & $\mathrm{Al}$ \\
\hline No. & 1 & 10.04 & 13.17 & 16.00 & 5.00 & 20.84 & 31.61 & 20.98 & 123.15 & 14.63 & 76.10 & 6.39 & 6.75 \\
\hline No. & 2 & 13.67 & 18.82 & 15.39 & 4.24 & 25.45 & 34.55 & 13.27 & 126.36 & 29.07 & 255.00 & 5.31 & 8.93 \\
\hline No. & 3 & 8.55 & 13.05 & 16.20 & 4.05 & 14.04 & 36.00 & 14.70 & 120.00 & 22.65 & 150.00 & 4.81 & 6.82 \\
\hline No. & 4 & 12.50 & 15.10 & 15.31 & 3.78 & 23.88 & 43.44 & 14.06 & 134.28 & 30.31 & 186.37 & 6.07 & 9.81 \\
\hline No. & 5 & 9.33 & 21.14 & 11.66 & 3.50 & 11.94 & 35.63 & 9.64 & 169.43 & 14.46 & 149.09 & 3.36 & 6.09 \\
\hline 平均 & & 10.82 & 16.26 & 14.81 & 4.11 & 19.23 & 36.25 & 14.53 & 134.66 & 22.22 & 163.11 & 5.19 & 7.68 \\
\hline
\end{tabular}

(Ac : Ac. Pht. Al : Al. Pht.)

第 5 表 $\mathrm{CCl}_{4}$ 注射家鬼歲器 Pht. 值 (S. J. R. 単位)

\begin{tabular}{|c|c|c|c|c|c|c|c|c|c|c|c|c|c|}
\hline \multirow{2}{*}{ 家艆番号 } & \multirow{2}{*}{ 注射後日数 } & \multicolumn{2}{|c|}{ 肝 } & \multicolumn{2}{|c|}{ 副 腎 } & \multicolumn{2}{|c|}{ 脾 } & \multicolumn{2}{|c|}{ 腎 } & \multicolumn{2}{|c|}{ 聅腸上部 } & \multicolumn{2}{|c|}{ 骨 噵 } \\
\hline & & Ac & $\mathrm{Al}$ & Ac & $\mathrm{Al}$ & Ac & Al & Ac & $\mathrm{Al}$ & Ac & $\mathrm{Al}$ & Ac & $\mathrm{A} 1$ \\
\hline No. & 2日 & 10.44 & 7.13 & 14.20 & 3.41 & $23.13 !$ & 26.88 & 16.09 & 142.50 & 15.63 & 17.03 & 8.63 & 5.94 \\
\hline No. 32 & 2 日 & 8.26 & 13.01 & 13.12 & 5.03 & 18.00 & 45.41 & 16.17 & 222.75 & 19.94 & 127.72 & 6.18 & 7.19 \\
\hline No. & 2日 & 5.10 & 10.05 & 11.18 & 2.05 & 8.48 & 13.90 & 12.75 & 149.63 & 24.50 & 86.52 & 9.98 & 6.90 \\
\hline No. & 3日 & 12.00 & 7.85 & 19.07 & 7.27 & 21.28 & 35.68 & 15.41 & 59.08 & 25.14 & 58.70 & 6.81 & 2.66 \\
\hline No. & 4 日 & 11.79 & 6.92 & 16.12 & 3.65 & 21.32 & 46.02 & 20.29 & 191.47 & 21.35 & 128.00 & 9.81 & 9.88 \\
\hline No. & 5日 & 9.02 & 19.47 & 14.86 & 1.62 & 24.18 & 32.23 & 14.57 & 135.60 & 23.31 & 45.26 & 7.20 & 4.52 \\
\hline No. & 7日 & 11.23 & 8.79 & 16.30 & 2.70 & 21.50 & 10.46 & 12.98 & 48.13 & 23.10 & 48.77 & 8.86 & 4.11 \\
\hline 38 & 11日 & 13.09 & 9.00 & $14.40^{\prime}$ & 5.00 & 27.90 & 7.28 & 15.32 & 135.32 & 31.01 & 119.68 & 9.57 & 7.40 \\
\hline & & 10.12 & 11 ? & 14.91 & 3.84 & 20.72 & & & & 22.99 & 78.96 & 8.38 & 6.08 \\
\hline
\end{tabular}

(Ac: Ac. Pht. Al: Al. Pht.) 
第 3 图 $\mathrm{CCl}_{4}$ 註射家雪 汗 Ac. pht.

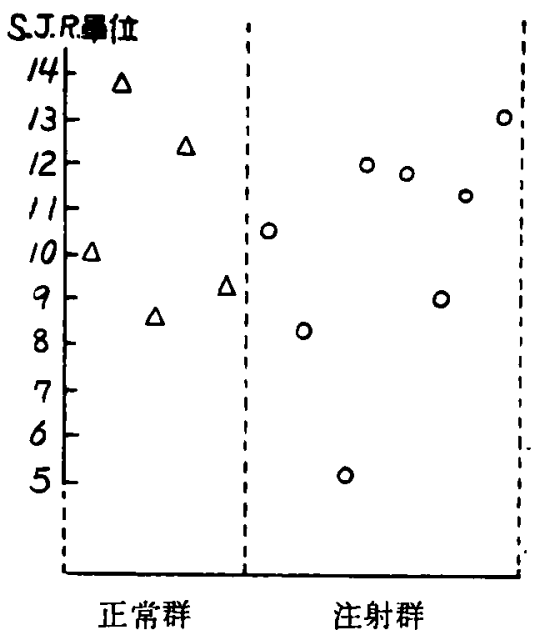

第5図 $\mathrm{CCl}_{4}$ 注射家鬼 副卧 $\mathrm{Ar}$. pht.

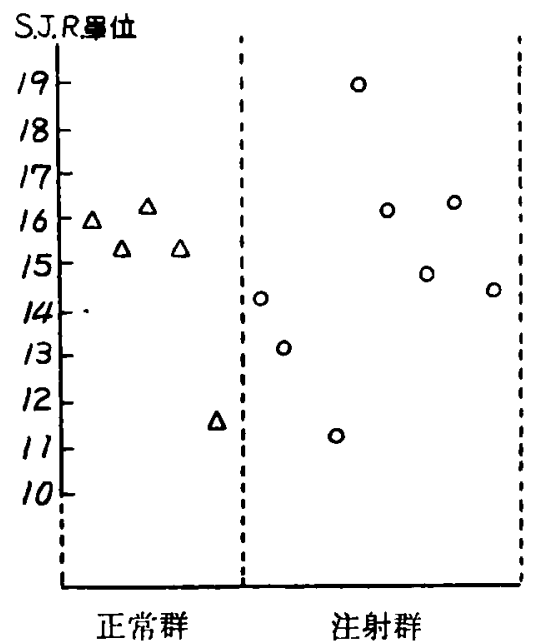

第 7 図 $\mathrm{CCl}_{4}$ 注射家乘 脾 Ac. pht.

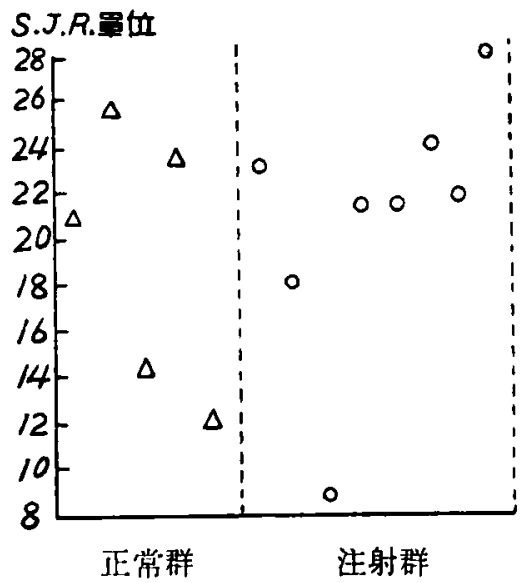

第 4 因 $\mathrm{CCl}_{4}$ 注射家鬼 肝 Al. pht.

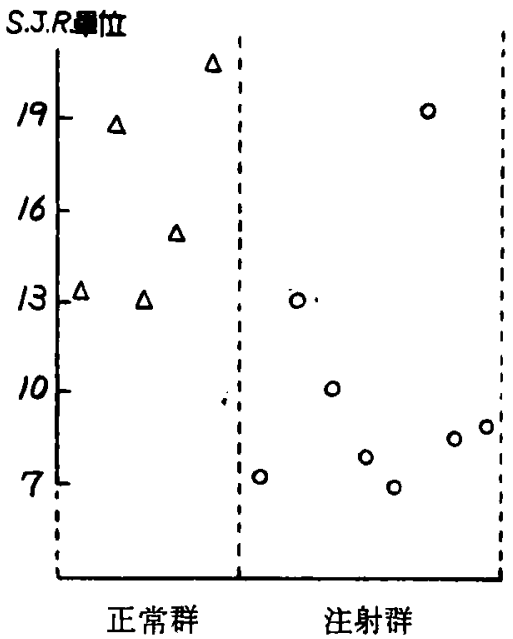

第6図 $\mathrm{CCl}_{4}$ 注射家鬼 副腎 Al. pht.

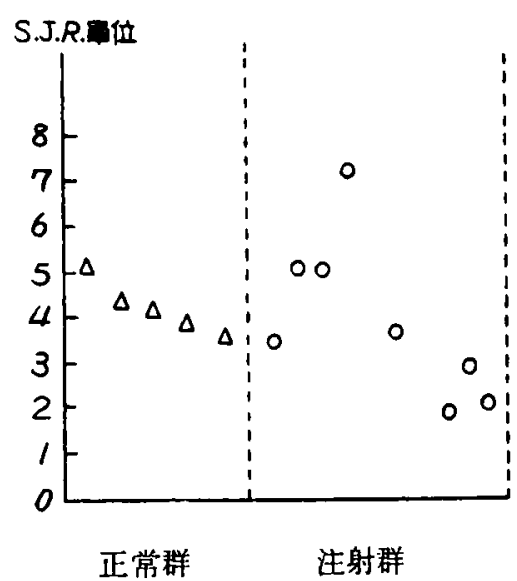

第 8 図 $\mathrm{CCl}_{4}$ 生射家雨 脾 Al. Pht.

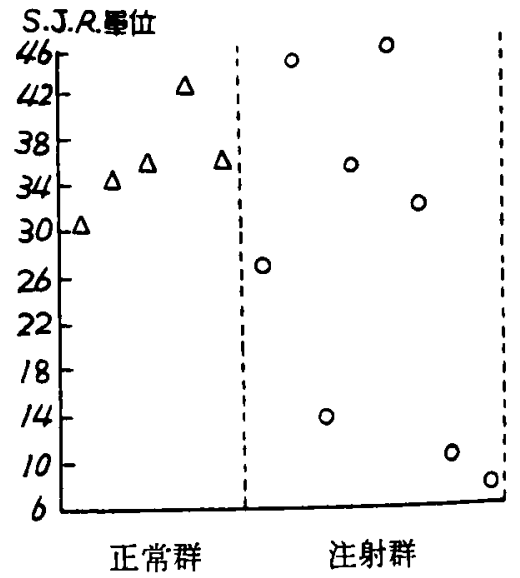


血清および藏器 Phosphatase の研究並び Phosphatase 産生について

第9図 $\mathrm{CCl}_{4}$ 注射家鬼肾 Ac. pht.

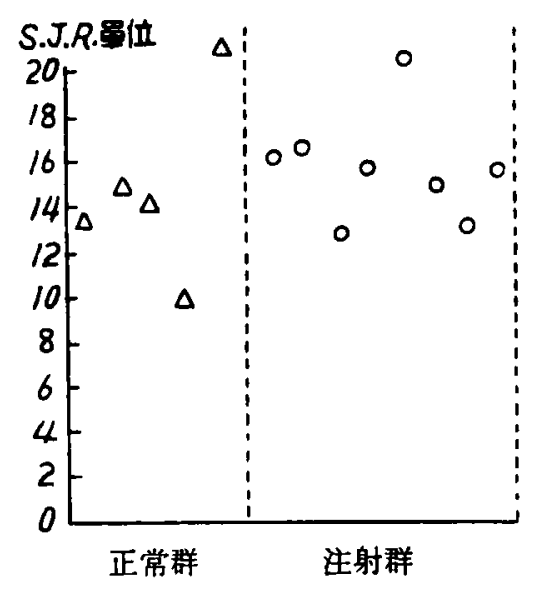

第11図 $\mathrm{CCl}_{4}$ 注射家鬼 空腸Ac. $\mathrm{Pht}$.

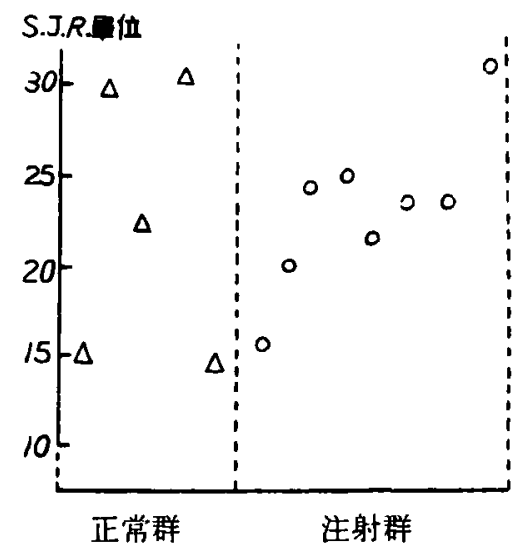

第13图 $\mathrm{CCl}_{4}$ 注射家鬼 骨䯣 Ac. Pht.

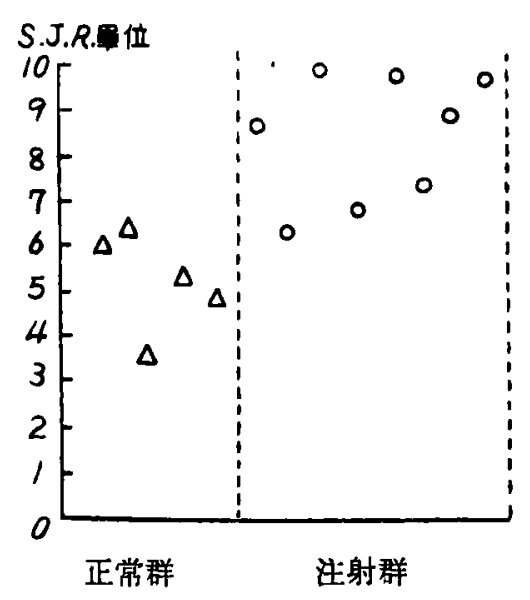

第10図 $\mathrm{CCl}_{4}$ 注射家鬼 腎 Al. Pht.

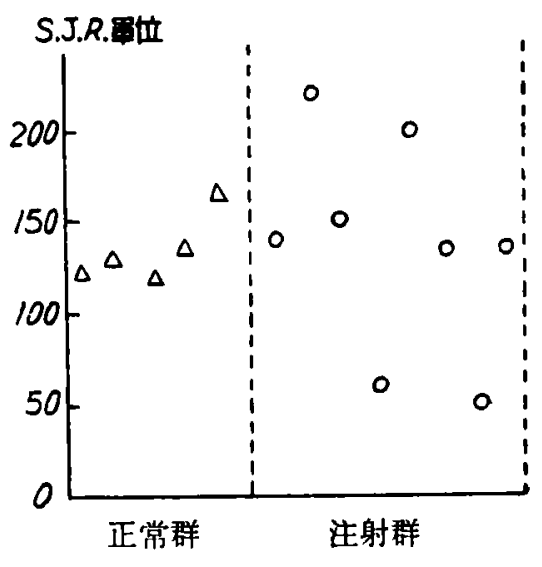

第12図 $\mathrm{CCl}_{4}$ 注射家鬼 空腸部 $\mathrm{Al} . \mathrm{Pht}$.

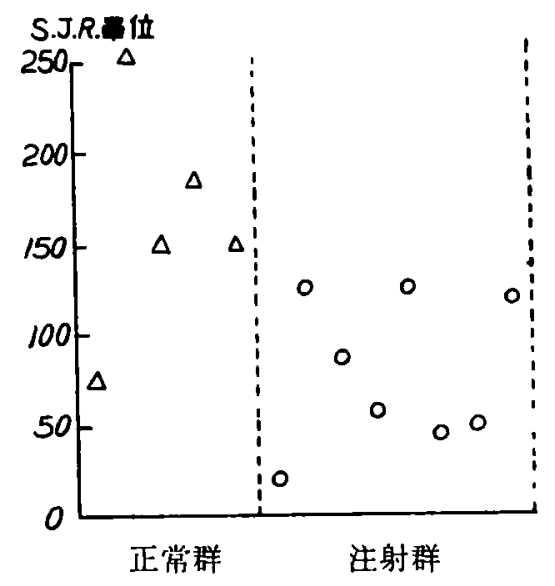

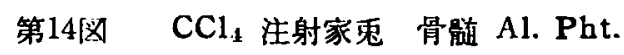

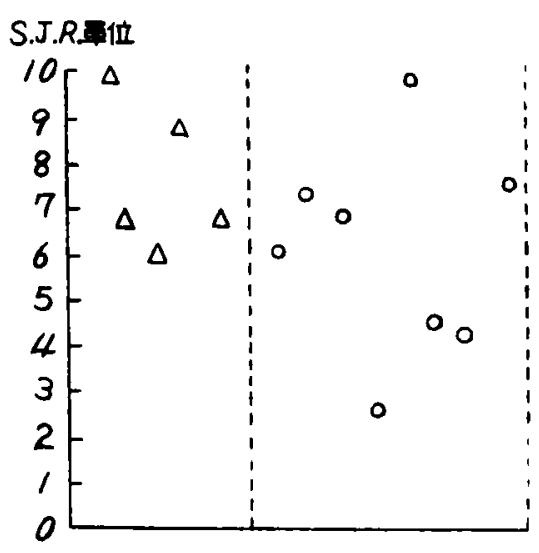

正常群注射群 
均値 10.12 を示し正常群平均値 10.82 に対し特別の変 化をみなかつた（第 3 図）。これに対し肝Al. Pht.は 平均值 10.28 を示し正常群平均値 16.26 に対し明らか な減少を認めた, (第 4 四). 肝 Al. Pht. の減少は $\mathrm{CCl}_{4}$ 注射後 2 日目のものも $4,5 ， 7 ， 11$ 日目のも つも同栚の减少を示しているのが注目された。

(口) 副督䑏器 Pht. 值, 副腎 Ac. Pht. は平均值 14.91 を示し正常群平均伯 14.81 に比し特異の変化を 認めなかつた（第 5 表, 第 5 㘠)。また副腎 Al. Pht. におおてても平均値 3.84 を示し, 正常群平均值 4.11 に 比し特異の変化を認めなかつた (第 5 表, 第 6 图).

(P) 脾缄器 Pht. 值, 脾 Ac. Pht. は平均値 20.72 示し正常家鬼群平均値 19.23 に比し特別の变化を認 めなかつた（第 5 表及ひ第 7 戌)，脾 Al. Pht.に括 い二は $\mathrm{CCl}_{4}$ 注射後 7 日, 11 日日の Al. Pht. の減少

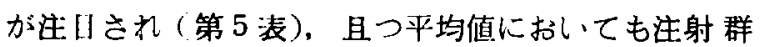
が 27.25 であるに对し，正常群のそれは 36.25 を示し て注射群脾 Al. Pht. の減少をみた（第万図）。

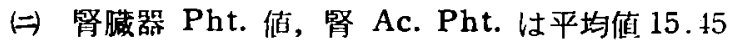
寺认し, 正常群平均値 14.53 に比し特異の变化示さ す（第 5 表及び第 9 汹)，また留 Al. Pht. に惊いて も平均値 135.31 を示し, 正常群平均値 134.66 に比 し特異の変化在己蒜かつた（第 5 表及ひ第10㸚)。

(林) 空腸上部臓器 Pht. 值, 空腸上部 Ac. Pht.は 平均値 22.99 示し, 正常群平均値 22.22 に比し，特異 の変化を認め心かつた(第5 表及ひ第11图)。これに対 し A1. Pht. は平均値 78.96 を示し, 正常群平均値 16 3.11 に好し著明な減少を認めた(第 5 表及び 第12|国).

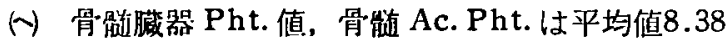
を示し，正常群平均值 5.19 に対し增加するのを認め た（第 5 表及び第13四)．こ机に対し骨噵Al. Pht. は 平均値 6.08 を示し, 正常群平均値 7.68 に対しい変化 は示さなかつたが軽度の減少倾向を示した。

\section{小括並びに考按}

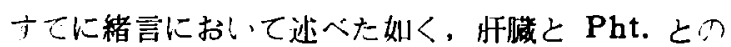
閜には密接な関係を有するものと考沉られ，肝疾患， 朋道疾患等のさいの Pht. の研究が綂けられ，さらに

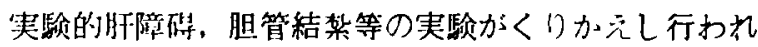
て*米な。とくに肝障碍時の Pht. の態度を究明するこ とは肝と Pht. との関倸を知る為には絶対必要のこ

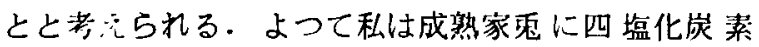
$\left(\mathrm{CCl}_{4}\right)$ を注射して朋障碍を起さしめて。，その血清及 び肝をはじめとする諸臟器の Ac. 放び Al. Pht. 在測 定した.

こもそも四程化炭素は 1835 年 Regnbult により癹
見された化合物であつて，藤井201 は四塩化岸素を家 鬼に経口的に 0.1，0.2，0.5，1.0g を投与し，組䑦 学的に $0.2 \mathrm{~g}$ 投与にてすでに肝に著明な退行変性を起 し， $0.5 \mathrm{~g}$ を投与すれば肝実質細胞は崩坡消失するほ か, 堅の采球体, 細尿管の退行変性, 心の脂肪曼洞か おこるのを認めた。すなわち $\mathrm{CCl}_{\mathbf{4}}$ は唆烈な器啠的変 化をおこす茟物で肝にみられる変化が最も強く、肝の 代謝障碍を来し，堅には機能障碍を来し，やや多量に 用いる時は心もまた強く犯されてくるものである.こ のように $\mathrm{CCl}_{4}$ は肝淢毒として古くより知られてお り，称"1'は家鬼を用いた $\mathrm{CCl}_{4}$ 注射に执いて生存道 最を定めた詳稩な実䮦を行い，生存投与量性皮下注射 にて毎 $\mathrm{kg}$ 0.2cc 以下としている. したがつて私は $\mathrm{CCl}_{4}$ の注射量を $0.1 \mathrm{cc}$ 毎 $\mathrm{kg}$ として皮下泩射を行つ た。

このような四塩化炭素のほかに，種々の薬物による 実跧的所障碍時の血清中のPht. の消長が研究されて おり、トルイレンヂアミン22223，フェニールヒドラ

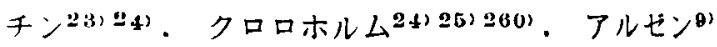
などによる実験的肝障碍により一般に血清中の

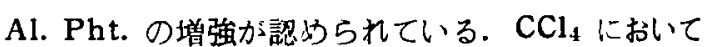
も田中ッ7) は投与後2 日目に执いて血清 Al. Pht. は最 高値を示したといつている．私の実験に执いても同じ く血清 Al. Pht. は2 日目において最高値を示した。 そして2 日目以後は急减して行くが, その减少は注射 前の正常值をさらに下つて減少し，11日目に执いても な怙減少の㑔向がみられた。血清 Ac. Pht.において も2 日目最高值を示し以後减少するのがみられた. こ のように $\mathrm{CCl}_{\mathbf{4}}$ 注射により血清 Pht.が一旦上畀する ことは， $\mathrm{CCl}_{4}$ による急激な肝障碍の為に肝の実質細 胞が障碍され，肝に执ける Pht. 生産が减少すると考 えられることと一見矛盾するように思えるが，これは 肝において生産された Pht.のほとんどすべてが䏣计 とよもに血中に移行するものと考えられ，たとえ肝に おけるPht. の生産が滅少しても血清中には一睡的に 增加するものと考えられる. したがつて增加後の血青 Pht.の減少は急激である。そとして血清 Pht. の减少か： 正常佰である旧値より更に低下を示したことは， $\mathrm{CCl}_{4}$ による肝障碍の為に肝に扔ける Pht. 笙生が低下した ことを意味するものである．胆计が血中へ移行するこ とは, 血清 Pht. の增加につれて血清ビリルビンの增 加がみられ，両者の間にはつきりした平行関倸はみら れなかつたが、ほほ平行する傾向にあつたことよりし てうなすかれる. 血清 Pht.の增加はそ机以外にも, 肝細胞障碍の為の血清 Pht. の排泄機能障碍も, 一部 
関与してくるものと思われる. 血清 Pht. の上䄯とそ の後の減少か，肝障碍による肝 Pht. の血中への移行 と肝 Pht. 産生の低下によるとする理由は， $\mathrm{CCl}_{4}$ 注射 家鬼の肝 Pht. の減少を来している事実に基つくもの てある. 肝 Ac. Pht. には変化をみなかつたか，肝 Al. Pht. に扔いては $\mathrm{CCl}_{4}$ 注射後 2 日〜11日のものの ほとんとに減少しているのを認めた。以上のことは $\mathrm{CCl}_{4}$ 注射後短時間のうちに起つておる梯で，米良 ${ }^{261}$ は $0.5 \mathrm{cc}$ 每 $\mathrm{kg} の \mathrm{CCl}_{4}$ を経口的に家鬼に投与し，投 与後18時間でその血清, 肝の Al. Pht. を測定して, 血清 Al. Pht.の軽度の上䄯と肝 Al. Pht. の軽度の 減少を来したと述へている。

以上のことより考うるに少くとも Al. Pht. は肝に 㧧いて産生されると考えるのが妥当と考えら机，肝起 源説に替意を表するものである.

副腎 Pht. 恃 Ac. 及ひ Al. Pht. ともに特別の変化 をみなかつたが，脾に怙いては脾 Ac. Pht. には特別

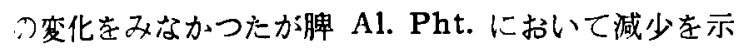
している.このことは同じく網内系の一環たる骨髄に おいて骨髄 Ac. Pht.の增加及び Al. Pht. の娍少傾 向がみられたことと関連して，あるいは網内系も Pht. の産生及ひ変動に幾分関与する事が考穴られるが，二 のことはまた後に墨汁による網内系充填家鬼について 述へる事とする。

督のPht. は腎加らの燐酸塩排泄に関与し，血中 Pht. の尿への排泄がある28 と考无られており，前 立腺と共に尿 Pht. の主要起源をなすものとされてい

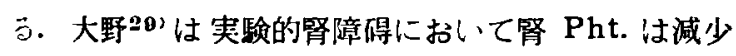
するといつている.また有溒る゙は弗菜中䓦時の腎 Ac.

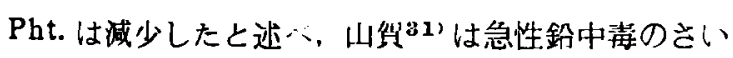
に腎 Al. Pht. は城少したこ述へている．しかし三島 ショは京しく鉛中毒に执いて堅の Ac. Pht., Al. Pht. こもに增強がられたと述心て扔り，波状を呈して変

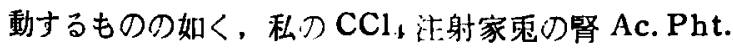
及ひ Al. Pht. は平均値において認むべき变化を認め なかつたが， $\mathrm{CCl}_{4}$ 注射後 2 日月の督 $\mathrm{Al}$. Pht.は3 日以後の Al. Pht. に比し軽度の增加傾向がみられた (第 5 表)ことは, やはり $\mathrm{CCl}_{4}$ による䝂障碍の結果 でないかと考える。

空渴上部部の Ac. Pht.に扔いては特筫の変化をみ なかつたが, Al.Pht.に括いて著しい減少をみた。を の作用機枟に関しては明らかでないが，久保流は副 惄摘仙による小腸上皮の A1. Pht. の著明な减少を認 めており，このような副腎機能の面と関係を有するよ うに思われる。あるいはまた後に胆管結㷊家鬼の項に
ついて述べる胆汁と小腸 Pht. の関係によるものも一 部あるものと考えられる.

以上 $\mathrm{CCl}_{4}$ による家象の肝障碍にさいして, 血清 Pht. の增加, さらにそれに引続く減少, 肝 Al. Pht. の減少を来し, 網内系たる脾, 骨随の Al. Pht. の減 少傾向並びに骨髅 Ac. Pht. の增加を来し, 肝のみな らす網内系も Pht. の変動に関与するものの如く、ま 太空腸上部の Al. Pht. の減少を来した。肝はやはり Pht. の産生に重大な意有するものと思われる。

\section{II 家鬼胆管結禁実験}

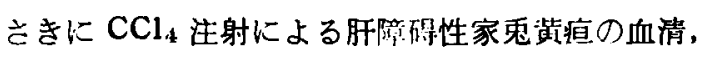
缄器 Pht. の变化を検索したが，肝障碍によらない胆 管閉塞性黄疸のさいには如何なる变化を起すかを明ら かにしたいと思つて, 私は家鬼の総輸胆管結愁切断 して黄㾝を起さしめて, その血清及び肝, 副堅, 脾,

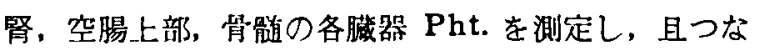
お血清ビリルビン量を併せ測定した。

\section{实焕動物並びに実骖方法}

実駼動物は成熟家鬼を使用した．家鬼を局所麻醉の もとに開腹しその総检胆管を 2 ケ所結禁してその間を 甽断した.術後 6 日目に材料在採取測定に供した.なお 対照として単に開腹のみを行つた家鬼についても问様 術後 6 日目に材料を採取測定した。血清ビリルビンは $\mathrm{CCl}_{4}$ 注射实卧の場合と同様 Jendrassik-Cleghorn 氏定量法変法19) に従つた。

\section{実験成紶}

（1）単開腹家鬼群血清 Pht. 值, 第6 表及び第 7 表 に示す如く，単開腹家鬼群においては術前及び術後 6 日目の血青 Pht. 值には变化を認めなかつた。すなわ 与血清 Ac. Pht. は術前値 0.31 術後 6 日目 0.37 , Al. Pht. は術前 4.45 で術後は 4.54 であつた。

(2) 単開腹家鬼群臟器 $\mathrm{Pht}$. 值, 単開腹家躳群にお

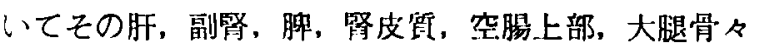

第 6 表

管開腹家鬼

血清 Ac. Pht.

\begin{tabular}{|c|c|c|}
\hline 家鬼番号 & 術 & 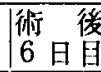 \\
\hline No. 39 & 0.25 & 0.31 \\
\hline No. 40 & 0.38 & 0.52 \\
\hline No. 42 & 0.31 & 0.40 \\
\hline No. 43 & 0.29 & 0.25 \\
\hline & 0.31 & 0.3 \\
\hline
\end{tabular}

(S. J. R. 単位)
第 7 表

単開腹家鬼 血清 Al. Pht.

\begin{tabular}{|c|c|c|}
\hline 家冡番号 & 術前 & $\begin{array}{l}\text { 菜 } \\
6 \text { 日後 }\end{array}$ \\
\hline No. 39 & 3.05 & 3.53 \\
\hline No. 40 & 6.82 & 5.28 \\
\hline No. 42 & 4.57 & 6.12 \\
\hline No. 43 & 3.34 & 3.21 \\
\hline & 4.45 & 4.5 \\
\hline
\end{tabular}

(S. J. R. 峃位) 
第 8 婊単開腹家香臓器 Pht. 値 (S.J.R. 単位)

\begin{tabular}{|c|c|c|c|c|c|c|c|c|c|c|c|c|}
\hline \multirow{2}{*}{ 家鬼番号 } & \multicolumn{2}{|c|}{ 肝 } & \multicolumn{2}{|c|}{ 副 腎 } & \multicolumn{2}{|c|}{ 脾 } & \multicolumn{2}{|c|}{ 腎 } & \multicolumn{2}{|c|}{ 空腸上部 } & \multicolumn{2}{|c|}{ 骨 檤 } \\
\hline & Ac & Al & $A c$ & Al & Ac & Al & Ac & Al & Ac & Al & Ac & $\mathrm{Al}$ \\
\hline No. 39 & 12.29 & 13.21 & 16.02 & 4.95 & 22.01 & 39.13 & 17.87 & 161.20 & 28.21 & 173.82 & 7.73 & 6.78 \\
\hline No. 40 & 9.89 & 19.89 & 17.87 & 4.00 & 22.95 & 35.12 & 15.04 & 135.21 & 25.37 & 118.87 & 4.62 & 8.91 \\
\hline No. 42 & 8.82 & 16.78 & 14.00 & 5.51 & 19.84 & 31.72 & 13.81 & 147.81 & 17.28 & 140.00 & 6.81 & 5.76 \\
\hline No. 43 & 9.30 & 15.89 & 17.73 & 4.38 & 22.18 & 37.21 & 16.14 & 118.35 & 19.86 & 159.93 & 5.45 & 9.98 \\
\hline 平，均値 & 10.08 & 16.44 & 16.41 & 4.71 & 21.75 & 35.80 & 15.72 & 140.64 & 22.68 & 148.16 & 6.15 & 7.86 \\
\hline
\end{tabular}

(Ac : Ac. Pht. Al : Al. Pht.)

第 9 表 胆管結絷家鬼血清 Ac. Pht.

\begin{tabular}{|c|c|c|c|}
\hline 家象番号 & 術 & 術後 4 日 & 術後 6 日 \\
\hline No. 44 & 0.40 & 1.04 & 2.00 \\
\hline No. 47 & 0.26 & & 2.46 \\
\hline No. 48 & 0.24 & 0.67 & 1.12 \\
\hline No. 51 & 0.30 & & 2.41 \\
\hline 平均値 & 0.30 & 0.86 & 2.00 \\
\hline
\end{tabular}

(S. J. R. 単位)
第10表 胆管結紮家忽血清 Al. Pht.

\begin{tabular}{|c|c|c|c|}
\hline 家鬼番号 & 術前 & 術後 4 日 & 術後 6 日 \\
\hline No. 44 & 3.89 & 28.39 & 30.67 \\
\hline No. 47 & 7.46 & & 19.84 \\
\hline No. 48 & 3.00 & 10.12 & 12.52 \\
\hline No. 51 & 6.20 & & 32.41 \\
\hline 平均值 & 5.14 & 19.26 & 23.86 \\
\hline
\end{tabular}

(S. J. R. 単位)

\section{第15図 胆管結禁家鬼} 血清 Ac. Pht.

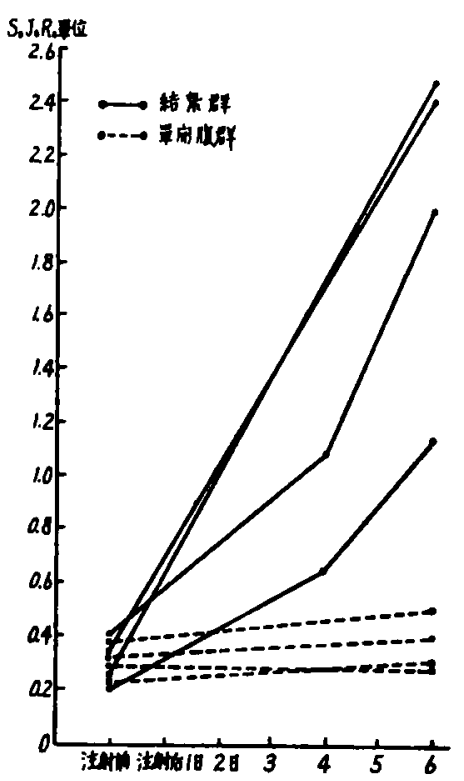

蹃の $0.5 \mathrm{~g}$ 在採取して測定した。第 8 表に示す如く で，血消 Pht. と同様に正常家鬼群に比し認むべき变 化はあらわ㣗ていい。

（3）胆管結热家鬼群血清 Pht. 俻, 血清 Ac. Pht., A1. Pht. ともに術後 4 日目すでに著明の增加をみ, 術後6 日目においてもなお比するのがみられ，術前
第16図 胆管結禁家鬼 血清 A1. Pht.

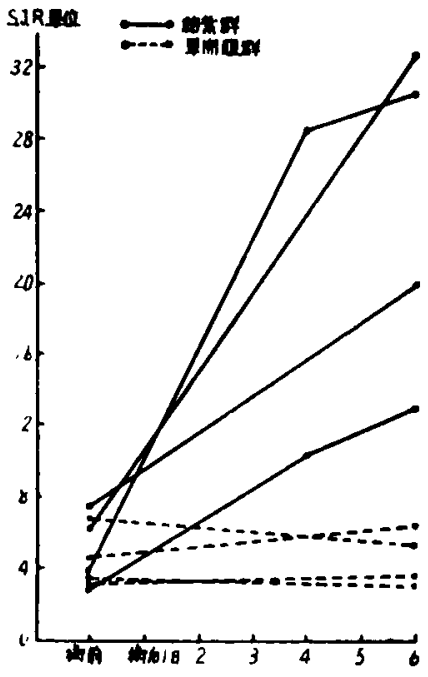

第11表 胆管結热家鬼 血清ビリルビン值 $(\mathrm{mg} / \mathrm{dl})$

\begin{tabular}{|c|c|c|c|}
\hline 家鬼番号 & 結絷前 & $\begin{array}{c}\text { 結禁後 } \\
4 \quad \text { 日 } \\
\end{array}$ & $\begin{array}{l}\text { 結蹵後 } \\
6 \text { 日 } \\
\end{array}$ \\
\hline No. 44 & 一 & 5.20 & 5.58 \\
\hline No. 47 & 0.20 & 5.73 & 6.14 \\
\hline No. 48 & - & 2.54 & 3.26 \\
\hline No. 51 & 一 & 4.37 & 4.35 \\
\hline
\end{tabular}

値の5〜6 倍に達している.殊に Al. Pht.の上䄯は 著しい。すなわち Ac. Pht. は平均值において術前 0.30 が術後 4 日目には 0.86 と上界し，6 日目には 2.0に達している（第 9 表及び第15図）.A1.Pnt.にお いても術前值5.14が術後4 日目 19.26 上上界し，6日 目には23.86に達している（第10表及ひ第16図）。 


\begin{tabular}{|c|c|c|c|c|c|c|c|c|c|c|c|c|}
\hline \multirow{2}{*}{ 家秃番号 } & \multicolumn{2}{|c|}{ 肝 } & \multicolumn{2}{|c|}{ 副 腎 } & \multicolumn{2}{|c|}{ 脾 } & \multicolumn{2}{|c|}{ 腎 } & \multicolumn{2}{|c|}{ 空腸上部 } & \multicolumn{2}{|c|}{ 骨 髄 } \\
\hline & Ac & $\mathrm{Al}$ & Ac & Al & Ac & $\mathrm{Al}$ & Ac & $\mathrm{Al}$ & Ac & Al & Ac & Al \\
\hline No. 44 & 18.17 & 23.18 & 17.89 & 4.92 & 32.77 & 20.57 & 32.29 & 145.71 & 27.43 & 134.74 & 16.39 & 16.27 \\
\hline No. 47 & 13.44 & 12.26 & 21.98 & 6.03 & 22.95 & 12.13 & 17.87 & 39.18 & 22.95 & 83.28 & 9.84 & 4.13 \\
\hline No. 48 & 11.50 & 16.69 & 12.24 & 2.57 & 23.68 & 18.95 & 17.05 & 11.05 & 24.00 & 96.63 & 6.88 & 4.86 \\
\hline No. 51 & 9.31 & 20.69 & 17.15 & 5.44 & 24.49 & 33.52 & 16.03 & 67.58 & 21.12 & 38.29 & 19.17 & 20.69 \\
\hline 平均値 & 13.11 & 18.21 & 17.32 & 4.74 & 25.97 & 21.29 & 20.81 & 65.88 & 23.88 & 88.24 & 13.07 & 11.49 \\
\hline
\end{tabular}

(Ac : Ac. Pht. Al : Al. Pht.)

（4）胆管結架家東群血清ビリルビン值，

第11表に示す如く, 術前定量し得ない迄 のものが術後4 日目すでに著しい增量を示 し，6 日目さらに上年またはその値を持綂 するのがみられた。

(5) 胆管結热家鬼群䑏器 Pht. 值, 術後 6 日目に材量を採取し肝, 副督, 脾, 倨皮 貿, 空腸上部, 骨䯣の $0.5 \mathrm{~g}$ 量の臟器 $\mathrm{Pht}$. を测定し第12表に示す結果を得た。各荿器 について記す。

(1) 肝溚器 Pht. 值 (第12表) 肝 Ac. Pht. は平均値 13.11 示し, 刘照群平均 值 10.08 に対し軽度の上年を(第17图)， また肝 Al. Pht. は平均値 18.21 を示し， 対照群平均値 16.44 に対しこれも軽度の上 男がみられた（第18图）か，いすれに招い ても極めて軽度で著しい変化は認め難いよ うである.

(D) 副腎䑏器 Pht. 值（第12表）。副腎 Ac. Pht. は平均值 17.32 を示し, 対照群 平均値 16.41 に対し特別の変化をみとめな かつた（第19図).またAl. Pht.に括いて も平均値 4.74 を示し対照样平均値 4.71 に 对しこれも变化を認めなかつた（第20因).

(v) 脾䑏器 Pht. 值 (第12表)。脾 Ac. Pht. は平均値 25.97 を示し対照群平均値 21.75 に比し軽度の增加がみられるが著し (変化江認められず（第21图)，また Al. Pht. は平均値 21.29 を示し対照群平均値 35.80 に比し減少しているのが認められた (第22目).

(A) 腎腰器 Pht. 值 (第12表)。觜 Ac. Pht. は平均值 20.81 示し, 対照群平均 傎 15.72 に対し軽度の增加が認められた
第17悯 胆管絶禁家鬼 旰 Ac. Pht.

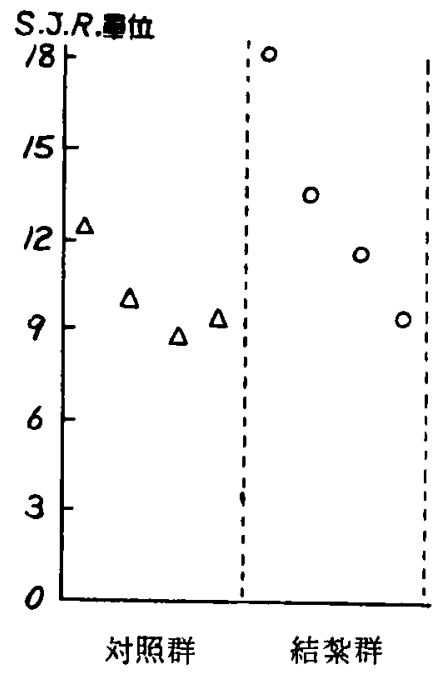

第19図 胆管結热家乘
副腎 Ac. Pht.

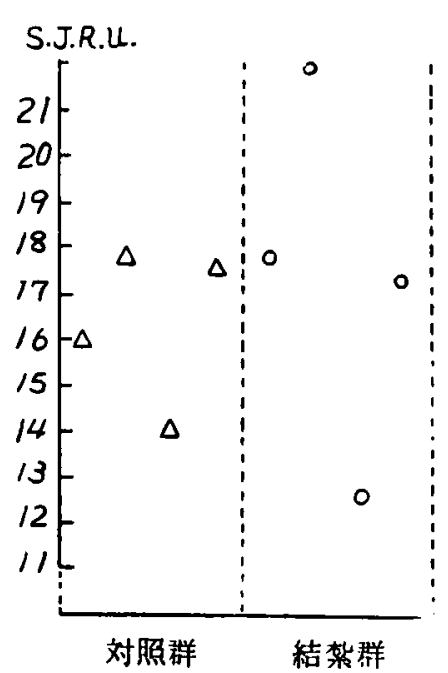

第18図 胆管結絷家秉 肝 Al. pht.

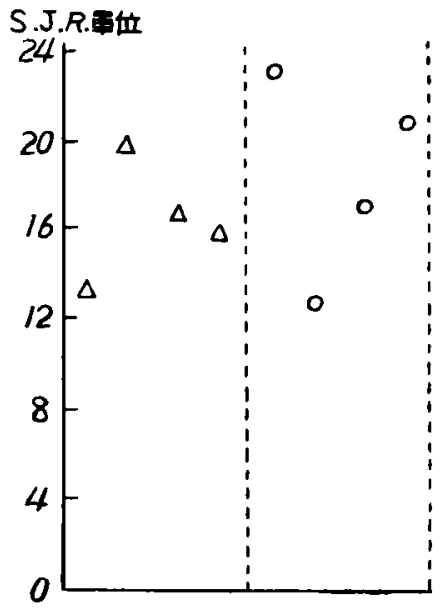

対照群 結紫群

第20図 胆管結柇家鬼 副管 A1. Pht.

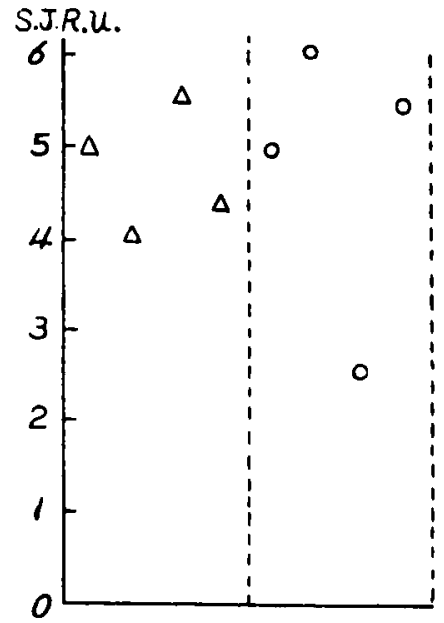

対照群 結禁群 
第21図 胆管結热家鬼 脾 Ac. Pht.

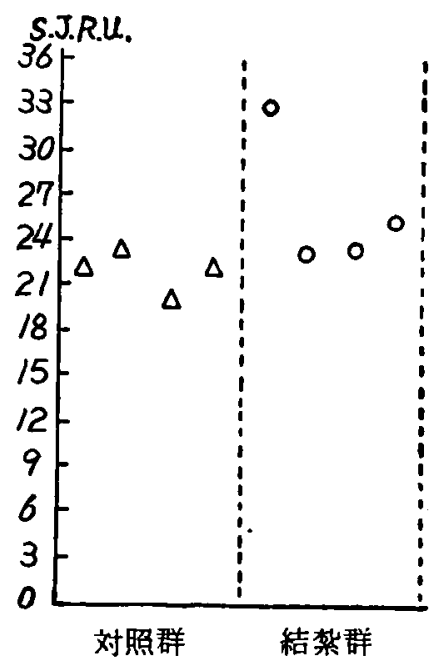

第23図胆管結禁家鬼

腎 Ac. Pht.

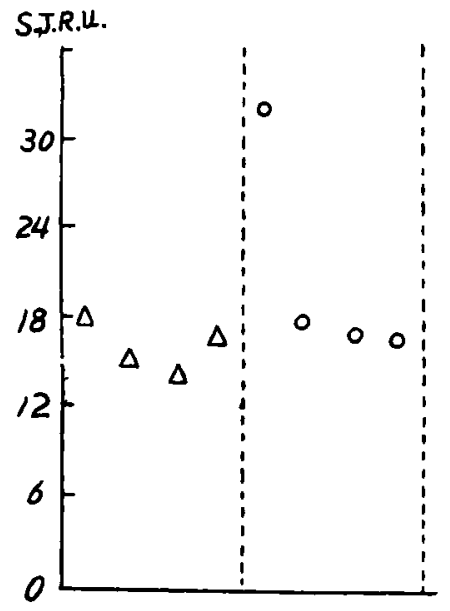

対照群結愁群

第25图 胆管結热家鬼 S.J.RU. 空腸上部 Ac. Pht.

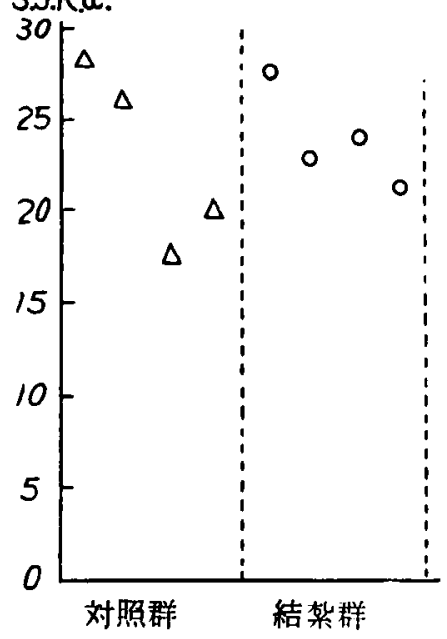

第22図

胆管結捸家鬼

脾 Al. Pht.

S.J.R.U.

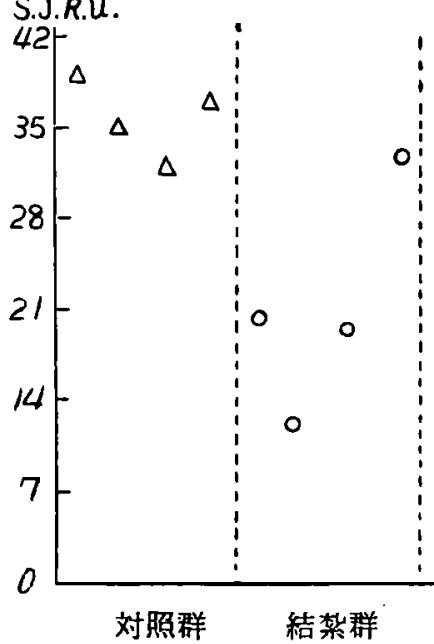

第24図

胆管結架家鬼 腎 Al. Pht.

S.J.R.U.

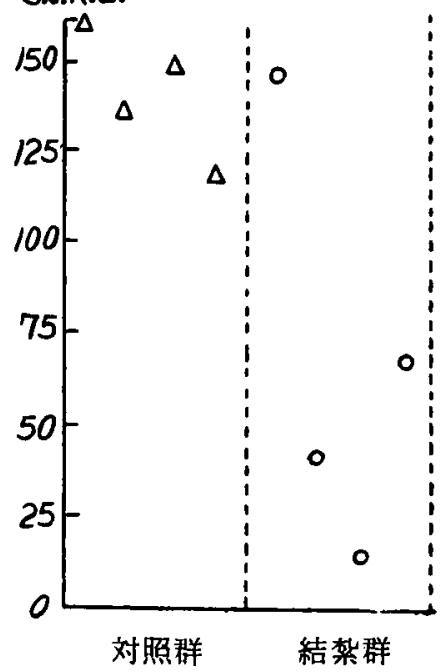

第26图 胆管結禁家鬼 空腸上部 Al. Pht.

S.J.R.U.

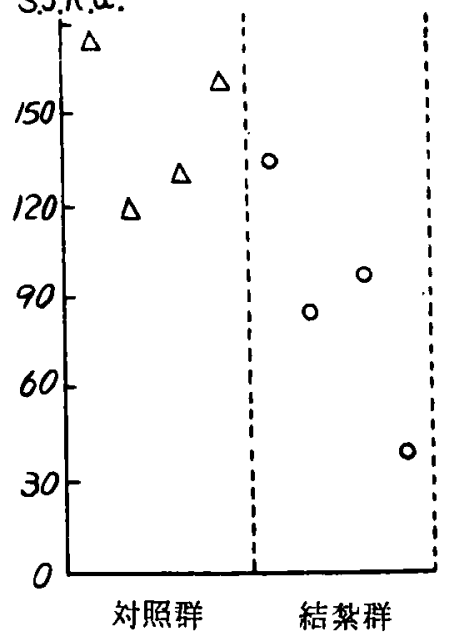

が、これはI例に高値を示したものがあ

り, 従つて平均値も上界をみたもので他 の3 例には特別の变化なく，従つて特異 の変化はないものと考えられる（第23 図). しかしAl. Pht. は平均値65.88 示し, 対照群平均値 140.64 K比し著し い减少がみられた（第24图).

(休) 空腸上部臟器 $\mathrm{Pht}$. 值 (第12表).

空腸上部 Ac. Pht. 怯平均値 23.88 存 示し対照群平均値 22.68 に対し変化をみ なかつたが (第25图)，Al. Pht.におい ては平均値 88.24 を示し, 対照群平均値 148.16 に対し著しい减少を示した（第 26四).

( ) 骨䯣搭器 Pht. 值 (第12表).

骨䯣 Ac. Pht. は平均値 13.07 を示し, 対照群平均值 6.15 に対し著しい增加在 みた（第27図）。 また Al. Pht. は平均 値 11.49 を示し，対昭群平均値 7.86 に 対し增加を示した（第28㘡）。

\section{小括並びに考按}

実医的に総輸胆管を結架して血清 Al. Pht. の消長を検索した実験は多く，犬 に就いては King a. Armstrong8"), Bodanshy a. Jaffe ${ }^{3)}$ にはじまり，家 鬼では Bauer ${ }^{35)}$, Wackstein u. Zak

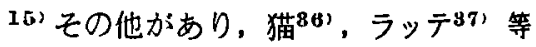
についても観察されている.それらによ ると動物の種類により総胆管結柇による 血清 Al. Pht. の增強の程度に非常な差 を有することが知られ，犬ては結箘によ り極めて高度の增強を起すか，猫，ラッ テでは軽微であり，家鬼は犬と猫の中間 に位するという。

一般に動物の総榆胆管を結柇すれれは血 清の Al. Pht. は著明に增加するのがみ られ，Jalling等 ${ }^{83}$ 'は家香血情 Al. Pht. は結架後直ちに上升し，15時間で正常值 の 5 20倍となると報告し, Wackstein a. Zak ${ }^{15)}$ は総胆管並ひに胆塞管結禁家 秉において血清 Al. Pht.は上年し，行 後48時間で最高檤を示し術前值の約 5 倍 に達したと述へている。 また白根 ${ }^{80}$ '及

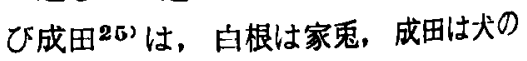



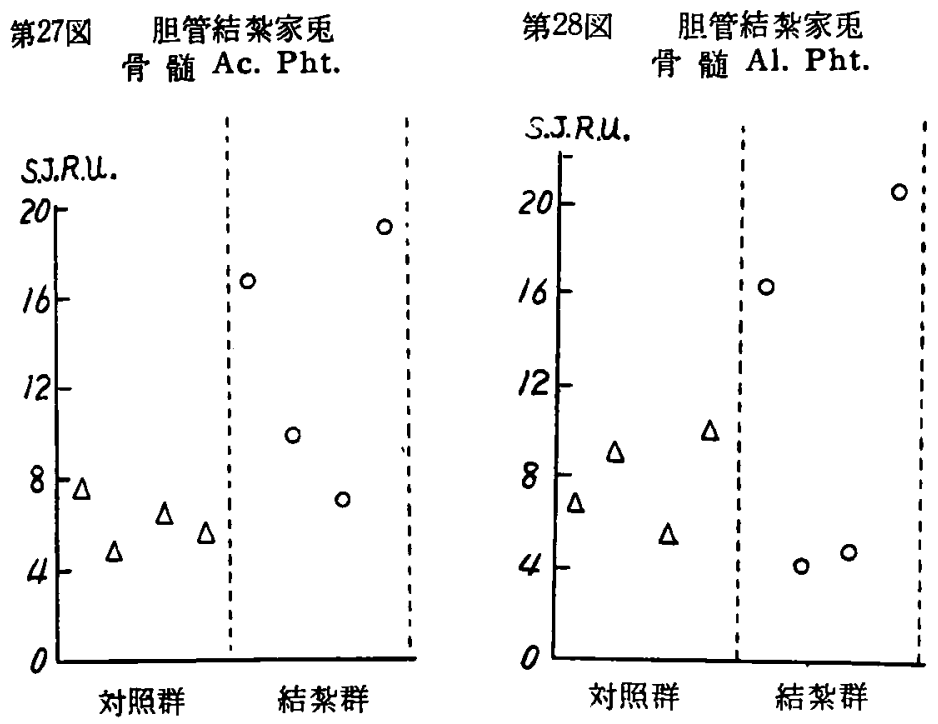

続し，両者間に不一致をみたと述べてい 3. Gut $\operatorname{man}{ }^{+1)}$. Freeman(s) 等も同 様の結果を報告している. 私の実臨にお いても血清ビリルビンの增加を認めた が，観察期間が 6 日であるので断定を下 し得ないが，6日間では血清 Pht. と血 清ビリルビンはほほ平行すると考えられ た.したがつて後述する肝 Pht, の著し い変化を認めなかつた点より, Pht.を多 量に含む胆汁が血中へ移行する為に血清 Pht.の上界がみられるものと考えられ る.

総胆管結禁と肝臟器 Pht. に関して は, 高橋は22が胆管結架犬に扔いて組織 化学的K, 肝 Al. Pht. は 10 12 時間 て肝細胞核, 原形質, Sinusoidに增加をみ，48時間 で更に著明に增加したと述へている。また武内43)は 家鬼の結禁性黄㡺の肝細胞の Al. Pht. 反応は增 強 し, 網状壊死巣には陰性であるが, その周辺の肝細胞 にはやや強いと述べている. これに反して米良”(は 胆管結惄後48時間の家鬼の肝剔出し, 肝灌流実输 行いクロロフオルム障碍肝に比し， $\beta$-Glycero 燐酸 ソーダの処理機能は低下を認めなかつたすすなわち肝 Al. Pht. には変化みみかつたと速へている. 旰 Ac.

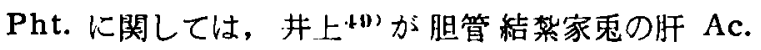
Pht. は組織化学的に12時間迄は减少するか， 24 時間 以後は增加すると述べている。

胆管結㷊による肝の組織学的变化は，暒本 ${ }^{-4+2}$ によ れば先ず胆管，胆毛細管のうつ滞が抽こり，ついで肝 稩胞は肥満膨大し，ついには細胞索を作ら内侧面すな わち毛細血管に面する部位において細胞膜の破損を来 し，うつ滞胆汁は毛緗血管に移行しついで肝綶胞は内 容の排除により縮少して萎樎し壊 死に括ち入るとい

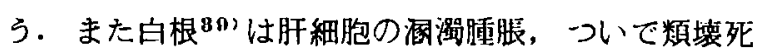
の出現をひ，最後に網状媛死坚の出現にややおくれて 胆栓形成をみいる.このように胆管結禁後長期にわ たれば肝の機能障碍を来すものであるが，福田ツタは 総胆管結势犬に一一定時日後胆整十二指晹吻合術を施し て, 血清 Al. Pht. の減少及び血清ビリルビンの减少 の急激なことより，胆管結柴による肝細胞の障碍は血 清 Pht. の排泄に若干の影があるかもしれないが， それも大した影裂はないものと考えると述へている. 私の胆管結禁家乘において, 肝 Ac. Pht. Al. Pht. 上 もに軽度の增加を認めたが著しい变化はみられすず，従 つて肝の Pht. 産生の低下は認められず, したがつて 
血清 Pht. の增加は胆汁が血中に移行する為に增加す るという確信を深めるものである. しかし血清 Pht. の增加の極く一部は、肝障碍による Pht. の排泄障碍 によるものであろうことは否み得ないと考えられる。

胆管結架時における他の臟器 Pht. に関してはその 文献をみない，副腎に関して前田46) は血液毒として ベンソールを家鬼に与えたさにに、Al. Pht. 反応が

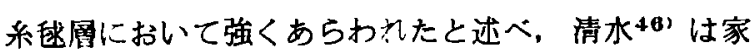
雨にアロキサンを注射して過血捃を起させ，網状層に A1. Pht. 反応が陽性にあらわれたのを認め, 岩下+7 汢雄ラッテに Diethylbesterol 注射して副腎 Ac. Pht. の增量を認めている.このように刺戟に対して 敏感に反応する副肾てはあるか，私の胆管結炛家鬼に おいてい Ac. 及び Al. Pht. ともに何ら認むべき变 化をみなかつた．従つて副腎と閉塞性䜤㡺との問には 梅別の関係がない様似思われる。

腎と黄疸に関しては，越宗がが黄疸患者の $50 \%$ に 尿の Al. Pht. の增加をみたが Ac. Pht. は变化をみ なかつたと述ハ，宮野にもも黄疸患者の尿 Al. Pht. に幾分の增量をみたと述へている。こ机に反し福田 吼は大の閉舆计黄疸にて尿 Al. Pht.には变化をみ なかつたと述へててい。尿 Pht. が腎及び前立腺に由 来する事は事実であり，また血中 Pht. の尿への排泄

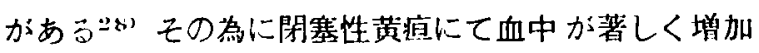
したさい，その調節をはかる為にある程度の負担はさ

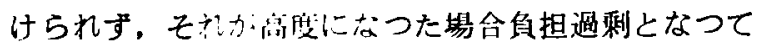
腎障碍を米なことが想像されるが，私の胆管結热家鬼 腎の Al. Pht. が箸しく減少を示したことは，その為 によるのでは心い思玑る。腎 Ac. Pht.は特放 の变化はみられなかつた。

空腸 Pht.は Deane a. Dempseyら1によれば, 組織化学的に正常空腸 A1. Pht.は䋐毛両側部に多く, Ac. Pht. 洨絆厄先端部に强くみられるという。井上 40)は胆管結热家鬼の小脂の Pht.反応を組織化学的に 検索して，結禁時間の経過と共に Al. Pht. は一時反 応が增殖するか，之の後漸次減弱するに対し，Ac. Pht. は一眭減少し後に渐次增强すると述べているが， 私の胆管結捼家雨に执いても同梯 Al. Pht. の減少が みられた。しかし Ac. Pht.においては特異の变化を

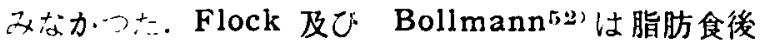
小腸リンパの Al. Pht. は上年するが、胆管閉寒また

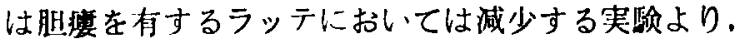
小腸に怙いて胆计は小晹粘膜からの Al. Pht.の出納 汇関与すると述へて扔り，Le Veen 等“8”は肝より 分泌された Pht.の一部は小腸より再吸収されるとい
う.したがつて胆汁又は胆汁内の Pht. が, 小晹 Pht. の Integrity と一定の関係を有する事が考えられ， 小腸 Pht.がその正常像を保持する為には, 少くとも 総胆管が開放されていることが必要であるものと思わ れる。

脾䑏 Pht.の生物学的意義はなお不明て，文献的化 もその報告をみないが，岩尾いせは领泉による家鬼の 藏器 Pht. の変化を組織化学的に検索して, 脾の Pht. の消失をみたといい，他の組秘 Pht. が正常傾向を有 するのに比して対蹠的であり，怙そらく Pht.は詝蔵 的な役割を演する脾内に䝑積され，必要に庍して動員 されるものと考えられると述へているがこれらのこ とから考えると、私の胆管結禁家鬼の脾 Al. Pht.の 減少は, 結热による血清 Al. Pht. の增加に伴!その 方に動員されたと考えられる. しかし Ac. Pht. は特 别の变化をみてい、ないか，こ礼は血清 Ac. Pht.の增 加が Al. Pht. の增加ほど著しくない事を元机ばう なつかれることである。このように考えると，脾ひい ては种内采が Pht.に対して演ずる役割の可成り大き いものである事に思いいたるものである.

このような脾 Pht.の変化に反して同じく網内采の 一環てある骨随においては，私の胆管結禁家鬼では骨 筩 Ac. Pht. の增加がみられ，また Al. Pht. に执い ても軽度の上年傾向がみられており，脾と趣を異にす るのであるが、骨蹃はもともと造血機能に重要な役割 を有し、ビリルビンを多量にふくむ結柇黄疸近夜に对 し何らかの刺戟をうけることが考こられ，それによつ て上記の変化を生じたと推察される。もれらの作用機 転等に開してはなお今後の研究にまたれははならない。

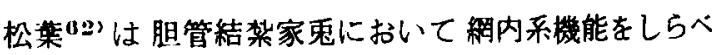
て, Kongorot 係数の增加老認め絧内系機能の诚弱あ りとしてるか、これのみでは説明し得ないと考えられ る.くりかえし述べる様に肝のみならず網内系も。 Pht. の変動に重要役制を演することが推察されるの である.

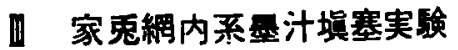

第 1 編に打ける癌エキス过射家鬼，また四盐化岸莱

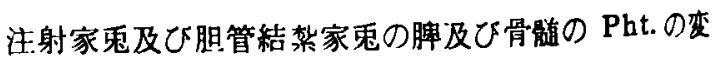
化よりみて、網内系が Pht.の産生或いは変動関し て何らかの役割を演することが推察されたので, 私は 墨汁を家躳に静注して稀内系を埧塞せしめ，その血清 及び䑏器 Pht.のAc. 及ひ Al. Pht. を测定しても の変動を観察した。 


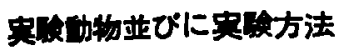

実駖動物には一定期間一定の飼料にて飼意された成 熟家鬼を用いた。絧内系埧塞には特別に作製した墨计 を用いた。墨计作慗には紅花墨を表面平骨な雨畑硯で 生理的食塩水を用いて徐々に研磨した，濃度を一定に する為に毛筆を以て和紙に書字して，下においた活字 印刷を辛うじて透見しうる程度とし，一時に多量に作 つて办室中に詝えておき，用に望んで滤舦で虑過した 後 $60^{\circ} \mathrm{C} 30$ 分間加温隇菌して, 家鬼体重 $\mathrm{kg}$ 毎 $5 \mathrm{cc}$ を耳静脈より静注した。注射方法は 1 日 1 回 6 日間連 続注射し，7日目に血清及ひ肝，副腎，脾，腎，空腸 上部，骨噵を採取测定に供した．なお稀内系機能検查 には Kongorot 法59、を用いた。

\section{实硂成转}

（1）墨汁填塞家鬼網内系機能，Kongorot 法によつ て测定したが第13表に示す如く，第 1 例は23.8，第 2 例目は17.4の Kongorot 指数の增加在認め、墨汁に よる家鬼網内系埧塞の効果あつたものと認められる。

（2）墨汁填塞家鬼血清 Pht. 値, 血清 Ac. Pht. は 墨计生射開始後 3 日目より减少示し 5 日目, 7 日目 の順に従つて減少し，平均値におい，て墨汁注射前0.35 が注射開始後 7 日目には 0.22 に减少するのがみられ た（第14表）。また Al. Pht.においても同様の减少 を示し，注射前 5.23 が注射開始後 7 日目には 1.92 に 减少しているのがみられる(第15表).
第13表 壆汁充埧家鬼網内系機能

\begin{tabular}{|c|c|c|c|c|}
\hline \multirow{2}{*}{ 家來番号 } & \multirow{2}{*}{ 体重 } & \multicolumn{2}{|c|}{ Kongorot 係数 } & \multirow{2}{*}{$\begin{array}{l}\text { Kongorot } \\
\text { 係数增减値 }\end{array}$} \\
\hline & & 埧塞前 & 填塞倦 & \\
\hline No. 52 & $1.95 \mathrm{~kg}$ & 37.4 & 61.2 & +23.8 \\
\hline No. 54 & $2.10 \mathrm{~kg}$ & 42.3 & 59.7 & +17.4 \\
\hline
\end{tabular}

第14表 網内系填塞家束血清 Ac. Pht.

\begin{tabular}{|c|c|c|c|c|}
\hline 家鬼番号 & 注射前 & \begin{tabular}{|c|c|c|} 
射開始後 \\
3
\end{tabular} & 日 & 日 \\
\hline No. 52 & 0.37 & 0.23 & 0.24 & 0.19 \\
\hline No. 54 & 0.32 & 0.30 & 0.27 & 0.24 \\
\hline 平均値 & 0.35 & 0.27 & 0.26 & 0.22 \\
\hline
\end{tabular}

(S. J. R. 単位)

第15表 網内系埧塞家躳血清 A1. Pht.

\begin{tabular}{|c|c|c|c|c|}
\hline 家秃潘号 & 注射前 & $\begin{array}{c}\text { 注射開始 } \\
3 \quad \text { 日 }\end{array}$ & 5 日 & 日 \\
\hline No. 52 & 5.95 & 4.50 & 3.05 & 2.62 \\
\hline No. 54 & 4.50 & 1.68 & 1.25 & 1.21 \\
\hline 平均値 & 5.23 & 3.09 & 2.15 & 1.92 \\
\hline
\end{tabular}

(S. J. R. 単位)

第 16 表

網内系填塞家愁葴器 Pht. 值

(S. J. R. 単位)

\begin{tabular}{|c|c|c|c|c|c|c|c|c|c|c|c|c|}
\hline \multirow{2}{*}{ 家鬼番号 } & \multicolumn{2}{|c|}{ 肝 } & \multicolumn{2}{|c|}{ 副 腎 } & \multicolumn{2}{|c|}{ 脾 } & \multicolumn{2}{|c|}{ 腎 } & \multicolumn{2}{|c|}{ 空腸上部 } & \multicolumn{2}{|c|}{ 骨 骮有 } \\
\hline & Ac & $\mathrm{Al}$ & Ac & Al & Ac & Al & Ac & $\mathrm{A} 1$ & Ac & $\mathrm{Al}$ & Ac & Al \\
\hline No. 52 & 8.28 & 11.70 & 13.97 & 5.21 & 14.94 & 5.22 & 10.80 & 114.00 & 16.50 & 184.50 & 3.12 & 4.20 \\
\hline No. 54 & 9.81 & 8.82 & 24.41 & 2.56 & 22.76 & 5.44 & 15.88 & 99.70 & 27.35 & 318.00 & 9.11 & 3.62 \\
\hline 平均値 & 9.05 & 10.26 & 19.19 & 3.89 & 18.85 & 5.33 & 13.34 & 106.85 & 21.93 & 251.25 & 6.12 & 3.91 \\
\hline
\end{tabular}

第17表 網内系填塞家鬼肝，脾，骨娟 Pht.

\begin{tabular}{|c|c|c|c|}
\hline & $\begin{array}{c}\text { 击 } \\
\text { Al. Pht. }\end{array}$ & $\begin{array}{c}\text { 脾 } \\
\text { Al. Pht. }\end{array}$ & 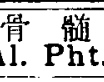 \\
\hline 正常家鬼平均値 & 16.26 & 36.25 & 7.68 \\
\hline 墨㚈埧塞家㭸平均値 & 10.26 & 5.33 & 3.91 \\
\hline
\end{tabular}

(S. J. R. 篻位)

（3）墨计虽塞家鬼䐵器 Pht. 值 (第16表).

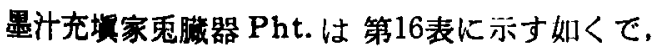
内系の一理考占める肝, 脾, 骨檤の Al. Pht. は正
常家鬼群のそれに比してすべて著しい減少を示してい るのか注目された（第17裴）. すなわち肝 Al. Pht. は平均値 10.26 示し正常家東群平均伯 16.26 に对し 减少し, 脾 Al. Pht. も平均值 5.33 示し正常群平均 値 36.25 に比し著しい珹少をみ，さらに盈噵 A1. Pht. も平均値 3.91 示し正常群平均佰 7.68 に対し减少を 亦している. また腎 Al. Pht. の柽度の减少及び空渴 上部の Al. Pht. の增加がみられたが，他には特別の 変化は認められなかつた。 


\section{小括並びに考按}

そもそも網内系とは肝、脾, 骨髄, リンパ腺等生体 内に広く分布しているところの発生学的. 生理学的及 ひ病理学的に特別な紐胞の総括的の名称であり，L. Aschoff55'（1913）かこれに網内系なる名称孝附した のにはじまり、この網内系を次の細胞群に分類してい，

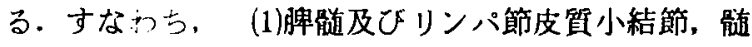
索及びその他のリンパ系組織の網内細胞，(2)リンパ 節の洞, 脾洞, 旰 Kupffer 氏星細胞, 骨䯣, 副肾皮 的及び下互体等の毛稩管内被，(3)組織球，(4)脾噵 稩胞，貪喰能ある単球．以上の 4 群に分類しており， (1)，(2)に属する細胞群を狄義の網内系と称した.いら い該細胞の本熊亚に分類に関しては種々論議が行われ ているが，現今網内系が著しい喰作用存有し機能的に 1 単位とみなし得る細胞群であることには，大体卧論 がないようである。

今日網内系の機能しして知られている主なものを挙 讨れば, 免疫体産生, 異物掑取貣喰機能, 含水淡素, 脂肪, 類脂体, 蛋白, 血色素跌, 体内水分調節等の内

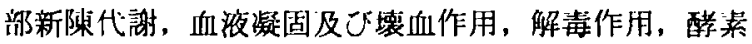
生成及ひ酸化作用並ひに胆汁色素生成等である。この ように生体の重要機能を司る網内系に対してその機能 を封鎖して, Pht.の变動をみることは興味すること と考穴られる。

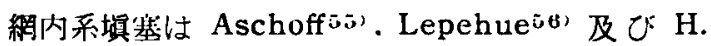

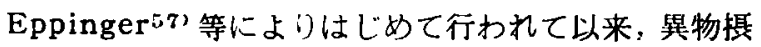
取により網内系がその機能を失うか否かに関して摩々 論議されて来た。そして網内系填塞には種々の楽郕が

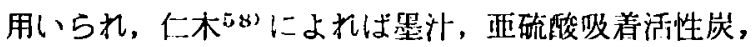
非吸着活性炭による網内系塓塞にさいして，活性岑は 墨斗に優るとも劣らぬ嫔塞剂であると述へているが。

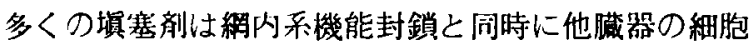
をも障碍せしめるものが多く，この点より墨汁は比較

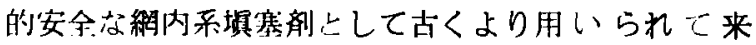

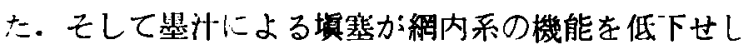
かることは, Alder a. Reimnn"1" の Kongorot 法

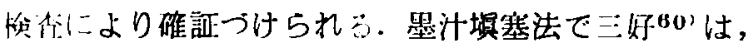
墨汁填塞家农では Kongorot 指数と皮下組維球の墨

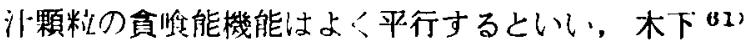
は大箸罢汁注入後 Kongorot 指数は明らかに低下し， 時間と共に忦復したが，少量を連絸注射すると却つて 機能六進を来すといつているか，しかし少星でも長期 にわたり投与する時は月的を達し得るに至るものてあ る. 過量投与は副作用を米卞危険があるから，必要に して月つ充分な量在投与するのか望ましい。

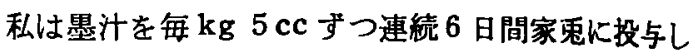
たが、明らかな Kongorot 係数の增加を認めたので， ほほ絧内系填塞は目的を達したものと考えられる。こ の時の血清 Pht. の変化は Ac. 及び Al. Pht. とも に注射開始後 3 日にしてすで減少がみられ，7 日に はざらに低下するのがみられた。このことは網内系買 塞により，血清へのPht.の移行がみられないか，ま たは肝またはその他における Pht. の産生が低下して いる事を示すものであつて，網内系が血清 Pht. に対 して重要な役割を演じていることを示すものである.

そしてまたさらに絹内系の主要器官であるところの 脾及び骨髄，肝の Pht. をみるに，その何れにおいて も㖑器 Al. Pht. の著しい减少が認められたことは注 日寸べきことであつて，和内系器官が Pht. を迎え入 れる事が不能の為か，或いはまた機能低下の為にPht. 産生の低下を来したものかは判然しないが，少くとも 網内系は Pht. 産生に対する一つの役都を演じている 事は想像出来る.また脾，骨㭪道，肝の Ac. Pht. は第 1 例日に执いては城少を分したが，第 2 例目において は脾，骨䯣の Ac. Pht. は增加を示している点をみる に, Ac. Pht. は複雑な機転において変化するものの 如く，亡らに高度の皟塞によつて低下すると想像せら れるか，ともあれ墨汁による網内系填塞に対して変動

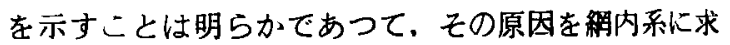
めるとしても妥当ではないかと考える。

また骨 Al. Pht. の低下, 空晹 Al. Pht. の增加下 ついてはその機転について明らかでないか，留 Al. Pht.の減少は腎障碍に基くものと想像され，また空 腸 Al. Pht. の增加は小晹の滥吸収作用の低下を示す

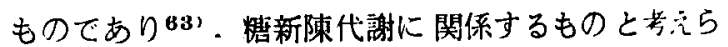
れる。

その他の蔵器に执いてい特翼の変化をみず，網内采 埧寒に対し影響を受けないものと考える。

\section{総括並びに考按}

以上各実騟により得た成績を要約すれば，四監化岸 素による肝障磦家鬼の血清 Ac. 及び Al. Pht. はとも に增加を来すが，時日の経過につれ急激な城少をみ， 血清 $\mathrm{Al} . \mathrm{Pht}$. においては $\mathrm{CCl}_{4}$ 投与前よりもさらに 隇少して低值を示し，11日に至るもな拉减少の経過を 示した。この時の肝 Ac. Pht.には著明な変化をみな かつたか，旰 Al. Pht.においては堿少を示した。 のことは肝における $\mathrm{Pht}$. 産生の低下を意味するもの

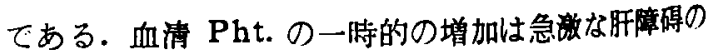
為に、肝において生産されていた Pht.のすへでが 
特的に胆计とともに血中に移行するものと考えられ $\vec{a}$.

総胆管結禁家鬼においても，その血清 Ac. Pht.の 及じ A1. Pht. は著明に增加するが Al. Pht. の增加 はとくに著しい。この時の肝 Ac. Pht. 及分肝 Al. Pht. は特別の变化を示さず，肝における Pht.の産 生も正常とみられるペきも，この時における血清 $\mathrm{Pht}$. の著しい增加は，胆管結禁による肝障碍之のものによ るものではなくて，胆汁の胆管への排泄が阻害されて 血中に移行することにより起ると考えられ，この時の 肝 Pht. 及ひ胆计の血中移行は毛緗胆管外一つ溢出, あるいは Eppinger(34)のいう如く胆管の破裂機転等 によつて起るものと考えられる．閉塞性黄疸が長期に わたれば科細胞もまた障碍されるが，このこきの肝細 胞障碍は福田 ${ }^{28}$ によよれは Pht.の排泄に大きな 影製 はないといつているが，長期につたれで肝の Pht. 産 生も低下をみることは否み得ない。

また $\mathrm{CCl}_{4}$ 投与家鬼の血清 Al. Pht. の增加に比し 胆管結禁家鬼の血清 Al. Pht.の増加は著しく，血清 Pht.の增加加非閉塞性黄疸と閉塞性潢疸の鑑別 診断 に利用し得るという Roberts゙’の説に替意表する ものである.そしてまた非閉基性茫疸におる血消Pht. の增加か，閉塞性黄疾における血清 Pht.の㘿加に 比し低い值を示したことの一部は，前者においては後 者におけるよりも肝紐胞の障碍程度大にしに，肝にお けるPht.の生座减少した為であつて，Freemanめ のPht.の肝性起源説に賛意を洼广るもので方る。こ のように考える時，吸収性黄㾝における血清 Pht. ○ 変動に対して, 肝稩胞の高度の障碍は血海 Pht. をむ しう减少せしめる. 血清 Pht. の增加は一面肝細胞の 状態，他面胆道閉塞の程度に支配せられるものと考え られる。

こしてまた墨汁による網内采塂塞家㐓において，血 清の Ac. Pht. 及び Al. Pht. の娍少をみ，また肝， 脾, 骨髄の䐵器 Al. Pht. の著しい减少をみたここは 網内系と Pht. が密接な関係を有することを示すもの で.Pht. の産生及ひ変動に対して一つの役割を演し ているょうで，肝のほかに一部網内系もPht. 磨牛に 関与するものと考えられる。

副腎は $\mathbf{C C l}_{4}$ 注射及ひ胆管結絷，墨计による網内系 埧塞のいずれに対しても特異の变化去示さす，器留 的, 機能的変化を来さないもののようで, Pht. 産生 に対して特別の意義を見出し得なかつた。

咕は胆管結热家鬼において Al. Pht. の減少をみ， また量汁充填家秉においても Al. Pht. の軽度の城少
をみたのみで，他には特別の变化を見出し得なかつ た。閉塞性黄疸と腎に関して何らかの関係が存するよ らであるが，今後の研究にまたねばならない，堅は尿 Pht. の起源をなすと云われてをり28，黄疸時には尿 Pht. は增加の傾向にありあu2, ビリルビン一定の関係 を有するもののようである。

空腸上部の Al. Pht. は $\mathrm{CCl}_{\mathbf{4}}$ 注射, 胆管結禁の何 れにても減少を示した．胆汁の変化によつて減少す るもののようで，腸管が正常機能を保持する為には正 常胆汁の存在が必要と思われる. 秱内 系埧 塞 家鬼の A1. Pht. は增加を示した。

脾及ひ骨䯙は網内系の一環として Pht. の変動にあ ずかるものの如きも，脾はPht. の詝藏に関与するも のの様で調節的な作用を有しているものと思われる。 骨骮は墨汁の網内系充填により Al. Pht. の減少をみ たが、Ac. Pht. に対しては特異の变化を示さなかつ た.しかるに $\mathrm{CCl}_{4}$ 注射家鬼，胆管結禁家鬼において ふこのAc. Pht.はともに增加の傾向を示しており，骨 髄機能の刺戟による機能元進の為と考え5れ， $\mathrm{CCl}_{4}$ 注射家鬼, 胆管結禁家鬼の両者の血清 Ac. Pht. の增 加乞相まつて考える時，骨能は血清 Ac. Pht. の增加 機転に関与しているものと考えられる。

Ac. Pht. と Al. Pht. が血清においてはほぼ平行的 に增减するのがみられたが，肝，骨髄，坒腸，脾， 腎, 副堅においては胹器 Ac. Pht. 及び Al. Pht.の 增减は必らずしも平行せず，逆関係にあるものもみら れ，その起源に関しても同一には論じ得ないかもしれ ないが，以上の成續を綜合してみるに，Pht. (少くと も Al. Pht.) は肝に拉いて生産され，一部これに網 内采よりの生産が加わるものと考えるのが妥当である と確信するものである.

\section{䊅論}

わたくしは四塩化炭菜注射家鬼，総胆管結禁家鬼，

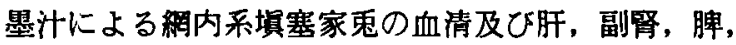
腎. 空腸, 骨髄の Ac. Pht 及び Al. Pht. を生化学 的に定量し次の結果告得た。

四塭化炭素注射家鬼においては，

(1) 血清 Ac. Pht., Al. Pht. ともに一過性に增加 し以後急激に隇少するが，Al. Pht. においては注射 前値よりさらに低值を示した。

(2) 血清ビリルビン值も増加に続いて減少した。

(a) 肝の Al. Pht. は减少を示したが Ac. Pht.は 变化をみなかつた。副腎 Pht. は何机にも变化を認め なかつた.脾の Ac. Pht. は变化なきも Al. Pht.は 
減少した。腎 Pht. も特別の変化をみなかつたが注射 後 2 日のものは 3 日以後のものに 比し軽度增加をみ た. 空腸の Ac. Pht.は变化なかつつたが Al. Pht.は 減少した, 骨䯣の Ac. Pht. は增加し Al. Pht. は減 少倾向を示した.

胆管結絷家鬼に扔いては

(1) 血清 Pht. は Ac., Al. Pht.ともに著しい上年 をみた。ことに Al. Pht. の上年は著しい。

(2) 血清ビリルビン値も上䄯した.

(3) 肝の Pht. は Ac., Al. Pht. はごく軽度增加 傾向あるも著しい变化はみられない．副腎 Pht.は变 化をみなかつた．脾の Ac. Pht. は特別の変化をみな いが Al. Pht.は減少した. 堅の Ac. Pht. は特異の 変化をみないか Al. Pht. は著しく减少した. 空腸の Ac. Pht.は变化ないが Al. Pht. は減少した。骨置の Ac. Pht.は增加を示しまた Al. Pht。も增加した。

文

1) Neuberg u. Karczag : Biochem. z., v. 36 , 1911.

2) Roberts : Brit. J. Exp. path., p. 90, v. 11, 1930.

3) Bodansky a. Jaffe : Proc. Soc. Exp. Path. a. Med., p. 107 , v. 31,1933 . ; do., p. 1179 , v. 31, 1934.

4 ) Roberts : Brit. Med. J., p. 734, v. 1, 1933.

5 ) King a. Armstrong : Canad. Med. Assoc. J., p243, v.33, 1935.

6) King a. Armstrong : Canad. Med. Assoc., p. 379 , v. $32,1934$.

7) Flood a. Gutmann : Amer. J. Physiol., v. $120,1937$.

8 ) Freeman, Chen a. Ivy : J. Biol. Chem., v. 123, 1938.

9) Winkelman a. Schiff mann : Arch. Int. Med., p. 919 , v. $63,1939$.

10) Ohno : Med. Klin., p. 1631, v. 23, 1927.

11) 大野：黄疸発生一元論, 1933.

12) 石橋 : 日本病理学会誌, 3, 153, 1939.

13) Armstrong, King a. Harris : Canad. Med. Assoc. J.. p. 14, v. 31, 1934.

14) Cantarow a. Nelson : Arch. Int. Med., p. 1045, v. 59, 1937.

15) Wachstein a. Zak : Am. J. of Clin. Path., p. 99 , v. $20,1950$.
种内系埧塞家鬼においては肝, 脾, 骨髄の Al.Pht. はすへて隇少を示したが Ac. Pht.は変化をみなかつ た.また血清 Pht.は Ac., Al. Pbt. ともに減少を 示した. 副腎 Pht. には変化なく, 堅の Ac. Pht.は 变化なきも Al. Pht. は減少を示した. 空腸の Ac. Pht. は変化をみないか Al. Pht. の增加をみた.

以上の結果より肝は Pht. (少くとも Al. Pht.)の 生産に関与し, 血清 Pht. 增减の起源となるものの如 く、さらに种内系も一部 Pht. 産生および変動に関与 しているものと思われる.

擱筆するに臨み，終始御懇篤なる御指導と御校閲在 睗わつた恩師津田名誉教授並びに砂田效授に深甚なる 感謝の意を表する。

なお本論文の要旨は昭和33年第33回中国四国外科学 会総会において発表した。

嗝

16) Burke : Gastroenterol., p. 660, v. 16, 1950.

17) 政山：大阪医学会雑誌, 40，3, 昭 16.

18) Shinowara J. R. : J. Biol. Chem., p. 921, v. 142,1942 ,

19) Jendrassik-Cleghorn : Bioch. Z., 289, 1, 1937.

20）藤井：児科誌, 大正13年, 990頁.

21）箖：京都府立医大誌，33，460, 昭16.

22) Bodansky : J. Biol. Chem., p. 14, v. 123,1938.

23）福田：長崎医誌, 23，4，226, 昭23.

24) Bodansky : Enzymol., p. 258, v. 3, 1937.

25）成田：東北医誌，53，5，469, 昭31.

26 ) 米良: 医学研究, 23，6，992, 昭28.

27) 田中：日大医誌, 11, 854, 昭27.

28) Domochowsky-Assenheim : Naturwissenschaften., v. 501, 1935.

29) 大野：日本生化学会報，16，3，昭16.

30) 有薗 : 和歌山医誌, 6, 1, 77, 昭30.

31）山賀：日本衛生学雑誌，9，2，78，昭29.

32) 三島: 国民衛生, 24, 2, 78, 昭30.

33) 久保:日本組織学紀要，6，4，653, 昭28.

34) King a. Armstrong : Can. Med. A. J., p. 14. v. $31,1934$.

35) Bauer : Acta Chir. Scandin., p. 228, v. 100 , 1950.

36) Cantarow : Proc. Exp. Biol. Med., p. 87, v. $35,1936$.

37) Dalgaard : Acta Phys. Scand., p. 310, v. 13, 
1947.

38) Jalling : Acta Phys. Scand., p. 70, v. 10, 1945.

39) 白根 : 東北医誌, 52, 4, 333, 昭30.

40) Balcells-Gorina : Rev. Espann. Fisisol., p. 155, v. 2, 1946.

41) Gutman : Proc. Soc. Exp. Biol. Med., p. 613 , v. $44,1940$.

42) 高橋: 東北医誌, 51, 6, 543, 昭30.

43) 武内 : 日病会誌, 33, 221, 昭18.

44）暒本；熊本医誌，7，1077，昭 6 .

45）前田：熊本医誌, 25, 392, 昭26.

46) 清水: 解剖学誌, 26,74 , 昭26.

47) 岩下: 日本泌尿器科誌, 41, 84, 昭25.

48) 越原：岡山医誌, 66, 8，1615, 昭29.

49) 井上：大阪大学医学誌, 4, 2,3,133, 昭27.

50) 宮野: 日本消化器病学誌, 47, 14 , 昭 25 .

51) Dean a. Dempsey : Anat. Rec., p. 401, v. 93, 1945.
52) Flock a. Ballman : J. Biol. Chem.,p. 792, v. 182, 1951.

53) Lè Veen : J. Lab. a. Clin. Med., p. 192, v. 36(2), 1950.

54) 岩尾: 温研紀要, 6, 4, 189, 昭29.

55) Aschoff : Ergeb. Inn.Med., p. 2, v. 26, 1924.

56) Lepehne : Münch. Med. Wschr., p. 342, v 26, 1922.

57) Eppinger : Klin. Wschr., p. 210, v. 691, 1923.

58）石木 : 神戸医大紀要，4，5，1138, 昭28.

59) Alder a. Reimann : Z. Exp. Med., p. 615, v $47,1925$.

60）三好：十全会誌，41，7，1222, 昭11.

61）木下：京都府立医 誌, 34，2，549，昭17。

62）松葉: 医学研究，23，3，413, 昭28.

63）新谷：日本医学及び健保，3260，2860, 昭16.

64) Eppinger : Verlage, Julius Springer, 801, 1937. 


\title{
Studies on Serum- and Organ-Phosphatase, and its Production
}

\section{Part II. Influences of Carbon Tetrachloride, Ligation of the Choledochus and Reticulo-endothelial System (R. E. S.) Blocking upon Serum- and Organ-Phosphatse}

By

\author{
Hitoshi KONISHI \\ from the Second Surgical Dept., Okayama University Medical School \\ (Director : formerly, Prof. emeritus Seiji TSUDA, M. D.
present, Prof. Terutake SUNADA, M. D.
}

Phosphatases in serum and organs (the liver, adrenal gland, spleen, kidney, jejunum and the bone marrow) were estimated biochemically after subcutaneous injection of $\mathrm{CCl}_{4}$, ligation of the choledochus and R. E. S. blocking by India ink, obtaing following results.

1) Following injection of $\mathrm{CCl}_{4}$ the phosphatases in serum were increased temporarily and later decreased markedly, but alkali phosphatase became below the level of which before injection. Also in the rabbits ligated the choledochus those, especially alkali phosphatase, were remarkably increased, and decreased in R. E. S. blocking.

2) After injection of $\mathrm{CCl}_{\mathfrak{l}}$ alkali phosphatse was decreased in the liver with no changes in the acid phosphatase, and no changes were observed in the liver after ligation of the choledohhus.

3) From the facts obtained in 1) and 2), it is concluded that phosphatases (at least alkali phosphatase) were produced in the liver.

4) In the R. E. S. blocking alkali phosphatase was remarkably decreased in the liver, spleen and the bone marrow.

This indicates that the R.E.S. plays an important role on the phosphatase, in cooporation with decrease of acid-and alkali-phosphatase in the serum.

5) Phosphatases in the adrenal gland have shown no changes by those procedures.

6) Phosphatases in the kidney were not changed by those procedures, with only exception of decrease in alkali phosphatase after ligation of the choledochus.

7) Alkali phosphatase in the jejunum was decreasd after injection of $\mathrm{CCl}_{4}$ or ligation of the choledochus, and increased after R. E. S. blocking.

8) The spleen is related to the storage of phosphatase and has a regulation effect.

9) Acid phospnatase in the bone marrow was tended to increase after injection of $\mathrm{CCl}_{4}$ or ligation of the choledochus, and alkali phosphatase was decreased after blocking of R.E.S. 